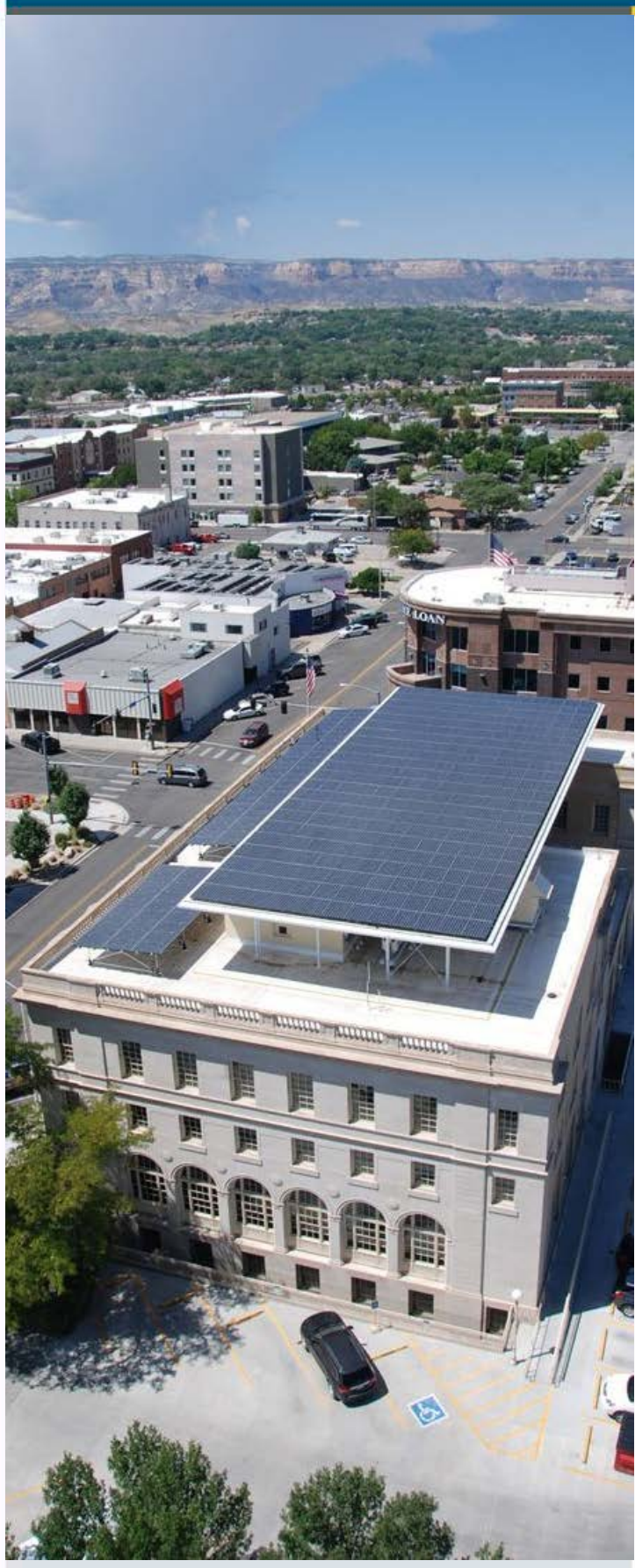

\title{
Aspinall Courthouse: GSA's Historic Preservation and Net-Zero Renovation
}

Case Study

Prepared by The National Renewable Energy Laboratory in partnership with the General Services Administration on behalf of the Federal Energy Management Program

R. Chang, S. Hayter, E. Hotchkiss, S. Pless, J. Sielcken, and C. Smith-Larney

October 2014 


\section{Contacts}

Jason Sielcken

General Services Administration

1 Denver Federal Center, Bldg. 41, Rm. 240

Denver, CO 80225

Phone: (303) 236-2972

E-mail: Jason.Sielcken@gsa.gov

Shanti Pless

National Renewable Energy Laboratory

15301 Denver West Parkway

Golden, CO 80401

Phone: (303) 275-3000

E-mail: Shanti.Pless@nrel.gov 


\section{Acknowledgments}

This document was prepared by the U.S. Department of Energy's National Renewable Energy Laboratory (NREL) in partnership with the General Services Administration (GSA) on behalf of the Department of Energy's Federal Energy Management Program (FEMP). The team is grateful to Sarah Jensen, FEMP's Sustainability lead, for making the Aspinall Courthouse case study and this document possible. The team also thanks all of the authors and reviewers, especially Alicen Kandt and Jimmy Salasovich at NREL, for their contributions. 


\section{Abbreviations and Acronyms}

$\begin{array}{ll}\text { ACHP } & \text { Advisory Council on Historic Preservation } \\ \text { ARRA } & \text { American Recovery and Reinvestment Act of } 2009 \\ \text { ASHRAE } & \text { American Society of Heating, Refrigerating and Air-Conditioning Engineers } \\ \text { Btu } & \text { British Thermal Units } \\ \text { E.O. } & \text { Executive Order } \\ \text { FEMP } & \text { Federal Energy Management Program } \\ \text { GSA } & \text { General Services Administration } \\ \text { HVAC } & \text { Heating, Ventilation, and Air Conditioning } \\ \text { M\&V } & \text { Monitoring and Verification } \\ \text { NHPA } & \text { National Historic Preservation Act } \\ \text { NPS } & \text { National Park Service } \\ \text { NREL } & \text { National Renewable Energy Laboratory } \\ \text { PV } & \text { Photovoltaic } \\ \text { SHPO } & \text { State Historic Preservation Office } \\ \text { ZEB } & \text { Zero-Energy Building }\end{array}$




\section{Contents}

Acknowledgments................................................................................................................................................................... iii

Abbreviations and Acronyms ....................................................................................................................................

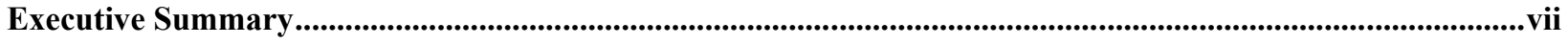

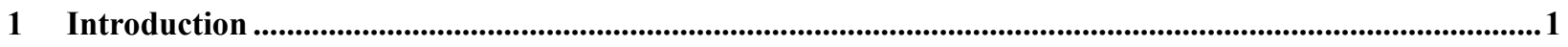

1.1 Net-Zero and Historic Properties ..........................................................................2

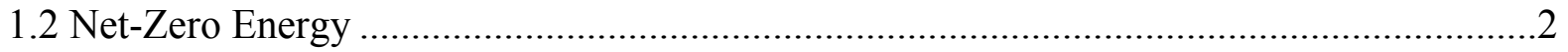

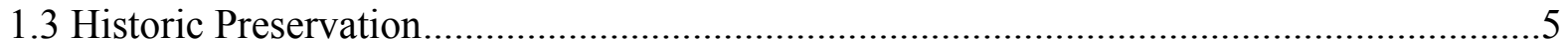

1.4 Net-Zero Design Complements Basic Design Principles of Historic Buildings ................7

2 Aspinall Courthouse Project Background.........................................................................................................................9

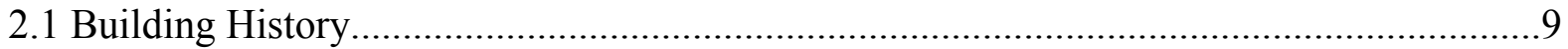

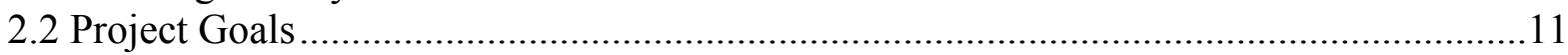

3 Aspinall Courthouse Renovation Process................................................................................................................12

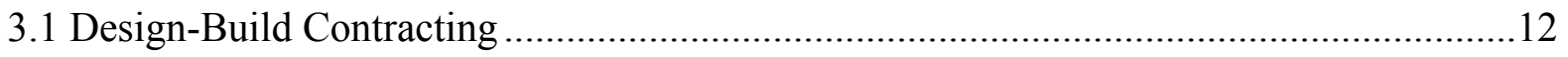

3.2 Principles of Net-Zero Design and Operations ................................................... 13

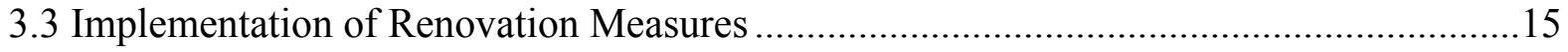

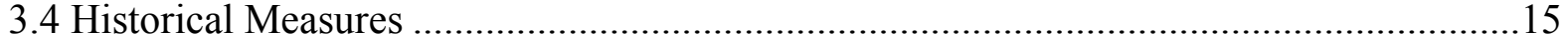

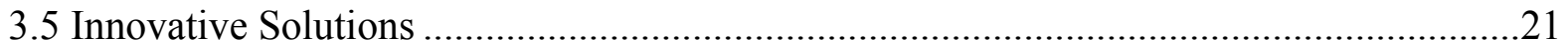

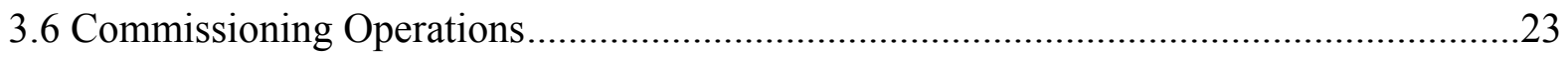

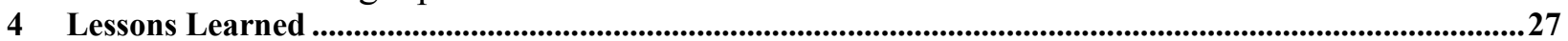




\section{List of Figures}

Figure 1. Federal building use (gross square feet) by building type ...........................................................................3

Figure 2. Illustrations of ZEB A classification (top) to ZEB D (bottom) ....................................................................4

Figure 3. The Aspinall Courthouse lobby circa 1938 .........................................................................................................6

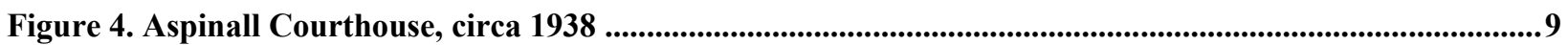

Figure 5. Aspinall Courthouse light well in the rear of the building, circa 2012 ................................................10

Figure 6. A modeled rendering of the Aspinall Courthouse façade ..............................................................................14

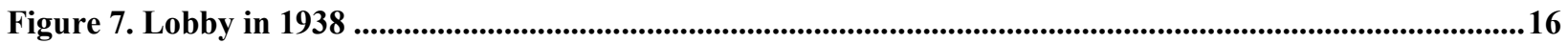

Figure 8. Lobby pre-construction (2010) ……………...............................................................................................16

Figure 9. 123-kW PV roof-mounted system ..............................................................................................................17

Figure 10. Aspinall Courthouse, north elevation, post-construction 2013 …......................................................18

Figure 11. Lobby post-construction in 2013 ...............................................................................................................19

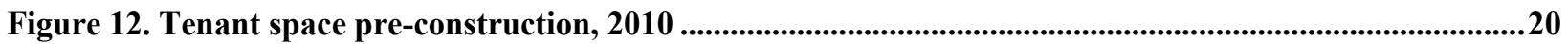

Figure 13. Tenant space post-construction, 2013 ..............................................................................................20

Figure 14. Modeled end-use electrical consumption in the Aspinall Courthouse .................................................23

Figure 15. Actual end-use electrical consumption as of February 2014 .....................................................................23

Figure 16. Energy use intensity comparison (March 2013-February 2014) ............................................................26

\section{List of Tables}

Table 1. Modeled Monthly Energy Consumption and Production ....................................................................14

Table 2. Baseline Versus Proposed Design Elements...........................................................................................................19 


\section{Executive Summary}

The Federal government is mandated with improving efficiency of buildings, incorporating renewable energy, and achieving net-zero energy operations where possible. As the largest owner of Federal buildings, the General Services Administration (GSA) is charged with managing and preserving buildings - more than one-quarter of which are listed or eligible for historic designation - in an efficient and sustainable manner. This challenge led GSA to consider aligning historic preservation renovations with net-zero energy goals. The agency chose the Wayne N. Aspinall Federal Building and U.S. Courthouse, to prove that net-zero energy goals can be achieved not only in an older building, but one that has a bevy of preservation requirements from being listed on the National Register of Historic Places.

The Wayne Aspinall Federal Building is a three-story building with nearly 42,000 square feet of office space located in Grand Junction, Colorado. The building was constructed in 1918 and originally functioned as a post office and courthouse. The building was listed on the National Register of Historic Places in 1980 and currently houses nine Federal agencies. Heavily in need of extensive repairs, the building was nearly slated for disposal; however, funding from the American Recovery and Reinvestment Act of 2009 (ARRA) paved the way for a major renovation project, focusing on historic preservation and energy efficiency upgrades. GSA aligned its sustainability and environmental goals with historic preservation requirements, necessitated by the Aspinall Courthouse's designation on the National Register of Historic Places. GSA leadership is aggressively pursuing avenues to eliminate — not just limit — the Federal government's impacts on the natural environment.

Through a design-build contract, the renovation project successfully met historic preservation requirements, the Guiding Principles for High Performance and Sustainable Buildings, and achieved goals towards reaching net-zero energy. In fiscal year 2008, prior to renovation, the site energy use intensity was $42.6 \mathrm{kBtu} / \mathrm{ft}^{2}$ and the annual energy cost was $\$ 0.79 / \mathrm{ft}^{2}$. Post-renovation energy use intensity, as of February 2014 , was $21 \mathrm{kBtu} / \mathrm{ft}^{2}$, with an annual energy cost of $\$ 0.53 / \mathrm{ft}^{2}$. The utility rate structure currently does not account for time-of-use or the rooftop photovoltaic system, which would lower the overall cost of the PV system. GSA expects that continued attention to energy-efficient operations and maintenance will reduce energy consumption and associated costs even further at the Aspinall Courthouse. The building currently achieves a status of a zero-energy building with the help of renewable energy both purchased from the utility and generated onsite.

This case study details the lessons learned from this unique achievement of both net-zero and historic preservation goals with the hope that facility managers across the country will be encouraged to set aggressive energy efficiency or net-zero goals for facilities that may be designated for historic preservation. The Aspinall Courthouse renovation is both preserving history and making history as the Federal government's first deep retrofit of a historic building that targets net-zero operations. 


\section{Introduction}

The General Services Administration (GSA) was established in 1949 to streamline administrative work of the U.S. Federal government. According to the GSA, the agency provides Federal facilities to more than 1 million civilian workers, oversees the preservation of more than 480 historic buildings, and supports procurement of goods and services from a broad range of commercial vendors. ${ }^{1}$ GSA owns and leases in excess of 354 million square feet of space in 9,600 buildings in more than 2,200 communities nationwide and manages properties that encompass a vast array of building types, including land ports of entry, courthouses, laboratories, post offices, and data processing centers. ${ }^{2}$ According to GSA, "more than one fourth of GSA's 1,600 owned buildings are listed in or eligible for the National Register of Historic Places, the nation's listing of historic properties, and approximately half are more than 50 years old."3 With such a large portfolio of historic buildings, GSA is faced with the challenge of managing an aging building stock and preserving a large number of the nation's historic properties.

The Federal government is mandated with improving efficiency of buildings, incorporating renewable energy, and achieving net-zero energy operations ${ }^{4}$ where possible. These challenges led GSA to consider aligning historic preservation renovations with net-zero energy goals. The Wayne N. Aspinall Federal Building and U.S. Courthouse (Aspinall Courthouse) in Grand Junction, Colorado, is an example of a renovation project that aimed to accomplish both historic preservation and net-zero energy goals.

When Congress enacted the American Recovery and Reinvestment Act (ARRA), \$4.5 billion was allocated to convert Federal buildings to high-performance green spaces, and another $\$ 750$ million was allocated to Federal building and courthouse renovations. Prior to receiving its portion of this funding, GSA was faced with the reality of managing an aging building badly in need of renovation, in the absence of the resources available even to consider such a project. Unable to support it, GSA was on the verge of disposing the old building when ARRA funds enabled GSA to change course to undertake the Aspinall Courthouse historic preservation and net-zero renovation project. This renovation is not only preserving history, it is making history, as the Federal government's first deep retrofit of a historic building that targets net-zero operations.

GSA has aligned its sustainability and environmental goals with historic preservation, necessitated by the Aspinall Courthouse's designation on the National Register of Historic Places. GSA leadership is aggressively pursuing avenues to eliminate, not just limit, the Federal government's impacts on the natural environment. GSA's FY 2012 Sustainability Plan reinforces this commitment:

GSA remains committed to leading the federal government towards a more sustainable future. GSA recognizes the important role it plays in facilitating sustainability goal achievement for other federal agencies. GSA will continue to identify and make available innovative, cost effective, and sustainable solutions for federal agencies. GSA will also continue to examine ways in which it can use its sustainability efforts to improve transparency of its operations; reduce costs and eliminate waste; improve accountability

${ }^{1}$ GSA Website: www.gsa.gov/portal/content/103369, Accessed September 23, 2014.

${ }^{2}$ GSA Website: www.gsa.gov/portal/content/103369, Accessed September 23, 2014.

${ }^{3}$ GSA Website: www.gsa.gov/portal/content/104832?utm source=PBS\&utm medium=printradio\&utm term=historicbuildings\&utm_campaign=shortcuts Accessed Feb 25, 2014.

${ }^{4}$ As required by Executive Order 13514 and the Energy Independence and Security Act. 
and agency performance management; and fully integrate sustainability into its day-today operations. ${ }^{5}$

GSA's ability and determination to align the historic preservation requirements that attend the Aspinall Courthouse with the agency's sustainability goals can serve as a guide for other Federal agencies to successfully manage similar projects. By highlighting the historic renovation of the Aspinall Courthouse, the U.S. Department of Energy's Federal Energy Management Program (FEMP) hopes that more Federal agencies will pursue net-zero projects for historic renovations. Each success brings net-zero building renovation and operation closer to the status quo, moves the Federal government closer to sustainable operations, and increases the nation's energy security.

\subsection{Net-Zero and Historic Properties}

The broad scope of the Aspinall Courthouse renovation project was developed to support the GSA's commitment to meet and surpass Federal requirements related to net-zero energy and sustainability goals. It lends context to the historic preservation element of the Aspinall story.

\subsection{Net-Zero Energy}

In 2012, nearly $40 \%$ of the total U.S. energy consumption (measured in British thermal units [Btu]) occurred in residential and commercial buildings. ${ }^{6}$ In commercial buildings, heating, ventilation, and air conditioning (HVAC) account for more than 1 trillion Btu, and lighting accounts for 1.3 trillion Btu. ${ }^{7}$ According to the Federal Real Property Profile, the Federal government owned and operated 3.3 billion square feet of property with a total of 361,000 building assets and a total operating cost of just over $\$ 24$ billion. ${ }^{8}$ Figure 1 illustrates the types of buildings that are owned and leased by the Federal government; offices comprise the largest building type within the Federal portfolio.

The greatest proportion of U.S. energy consumption is associated with buildings, and the Federal government is the largest owner and operator of buildings in the United States. The combination presents a potent Federal sector opportunity for large-scale energy reduction. With a building stock that includes every major building type in all climate zones, extensive industry partnerships, and personnel specially trained for world-class building systems research, the Federal government is in a unique position to lead the zero energy buildings initiative. Recent mandates and Executive Orders (E.O.s) acknowledge the need to ratchet up energy efficiency and the use of renewable energy.

\footnotetext{
${ }^{5}$ GSA FY 2012 Sustainability Plan www.gsa.gov/portal/mediaId/162943/fileName/GSA_FY2012_Sustainability_Plan.action

${ }^{6}$ U.S. Energy Information Administration; www.eia.gov/tools/faqs/faq.cfm?id=86\&t=1. Accessed Feb 2014.

${ }^{7}$ U.S. Energy Information Administration, Annual Energy Review 2011, Figure 2.11: www.eia.gov/totalenergy/data/annual/pdf/aer.pdf. Accessed Feb 2014.

${ }^{8}$ GSA Frequently Asked Questions about the Federal Real Property Profile (FRPP) www.gsa.gov/portal/content/104199. Accessed September 2014.
} 


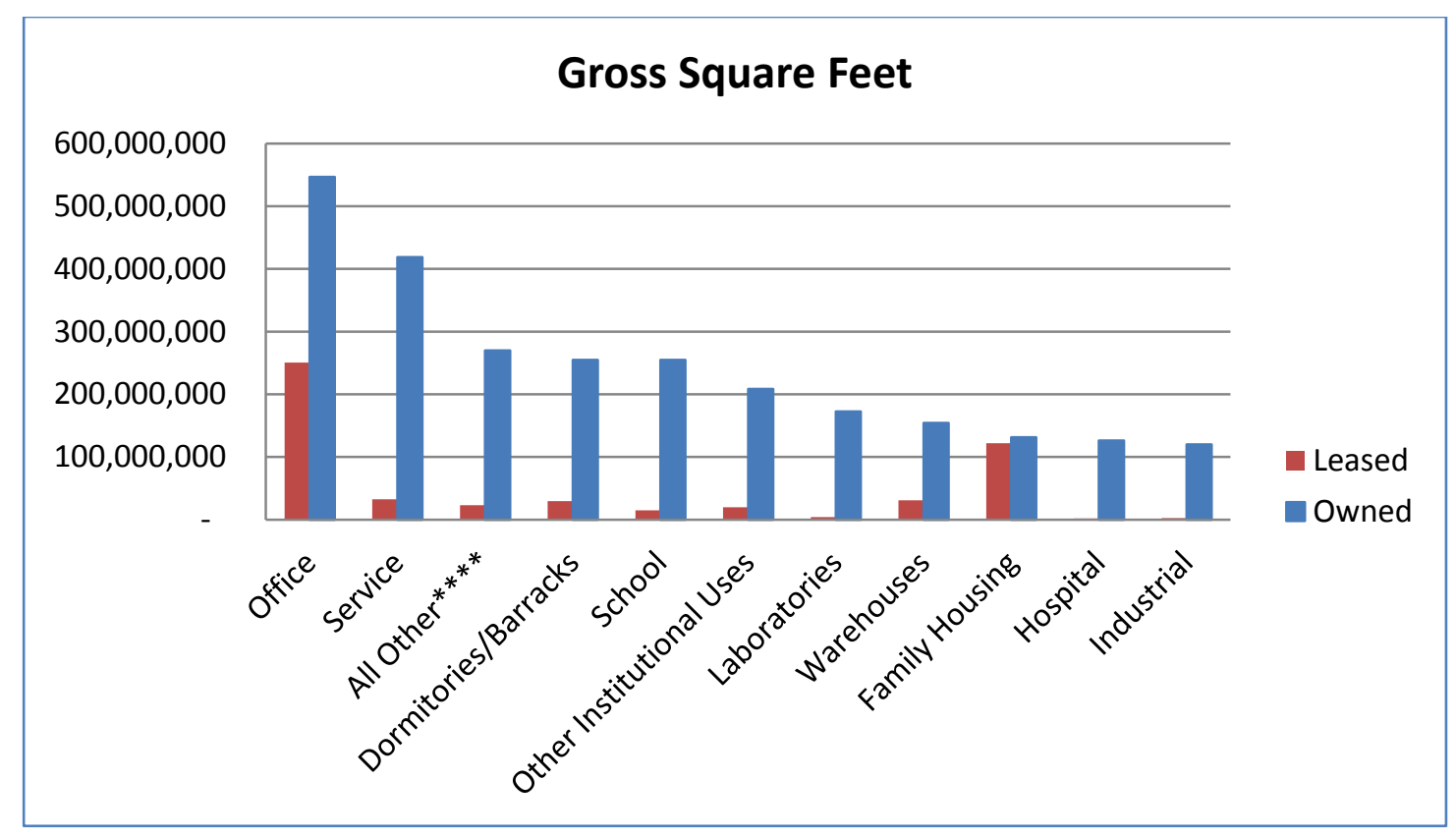

Figure 1. Federal building use (gross square feet) by building type Source: Federal Real Property Profile, GSA

The Energy Independence and Security Act of 2007 requires all new Federal buildings and major renovations to reduce fossil fuel-generated energy consumption over the next 16 years. Reductions are measured in comparison to a similar building in FY $2003^{9}$ and designs for new Federal buildings and major renovations must eliminate fossil fuel-generated energy use altogether (or achieve net-zero) by 2030. E.O. 13514, Federal Leadership in Environmental, Energy and Economic Performance, expands on Federal energy reduction and environmental performance requirements set in E.O. 13423, as well as outlines specific management strategies to improve sustainability, including managing existing buildings to reduce energy, water, and materials consumption. E.O. 13514 requires agencies to implement highperformance sustainable Federal building design, construction, operation and management, maintenance, and deconstruction by:

Ensuring all new Federal buildings, entering the design phase in 2020 or later, are designed to achieve zero net energy by 2030 [Section 2(g)(i)]

The net-zero design goal provides an optimal framework to support E.O. 13514's principal objective "to establish an integrated strategy towards sustainability in the Federal Government and to make reduction of greenhouse gas emissions a priority for Federal agencies." Successfully planning and managing netzero operations requires extensive integration of all building systems, resource use, and building occupant behaviors. In fact, net-zero operations can only be achieved through careful consideration of all energy use aspects of a building. Additionally, the net-zero design process satisfies the planning requirements of E.O. 13514 clause $(\mathrm{g})$ implement high performance sustainable Federal building design. Clause (g) requires Federal agencies to comply with the Guiding Principles for Federal Leadership in High Performance and Sustainable Buildings; any net-zero energy building already complies with the Guiding

${ }^{9}$ Similar buildings in FY03 as measured by the Commercial Buildings Energy Consumption Survey or the Residential Energy Consumption Survey data from the U.S. Department of Energy's Energy Information Agency. 
Principles by virtue of the processes and integration that are required first to reach net-zero feasibility and then to achieve net-zero operations.

A zero-energy building (ZEB) or a net ZEB is defined as "a building that has greatly reduced energy needs through efficiency gains such that the balance of energy needs can be supplied with renewable technologies." 10 Typically the definition of net ZEBs applies to the annual consumption and generation on site.

ZEBs can be classified in a hierarchical system, from " $A$ " to " $D$," based on the renewable energy location with respect to the building (onsite versus offsite). Figure 2 illustrates the ZEB hierarchy. The hierarchical approach emphasizes the following: ZEB A-a building that generates and uses energy through energy efficiency and building-sited renewable energy systems; ZEB B - a building that generates and uses energy through energy efficiency and renewable energy sited on the building and on the property/campus; ZEB C - a building that generates and uses energy through energy efficiency and renewable energy sited on the building, on the property/campus and offsite; and ZEB D-a building that conserves energy through efficiency measures, and generates energy through energy renewable energy sited on the building, onsite and through the purchase of offsite renewable energy credits.

A grid-connected ZEB uses the utility for energy balance, drawing energy from the grid when onsite generation from renewable sources does not meet loads, and exporting excess energy back to the grid when onsite generation is greater than the building's loads. ZEB designs should always address demand first by using all possible cost-effective energy efficiency strategies to reduce it, and then incorporate renewable energy to supply the remaining load.

The Federal government is targeting net ZEBs through innovative agency planning and action. It is important that the government lead by example and lay the groundwork to make net ZEBs
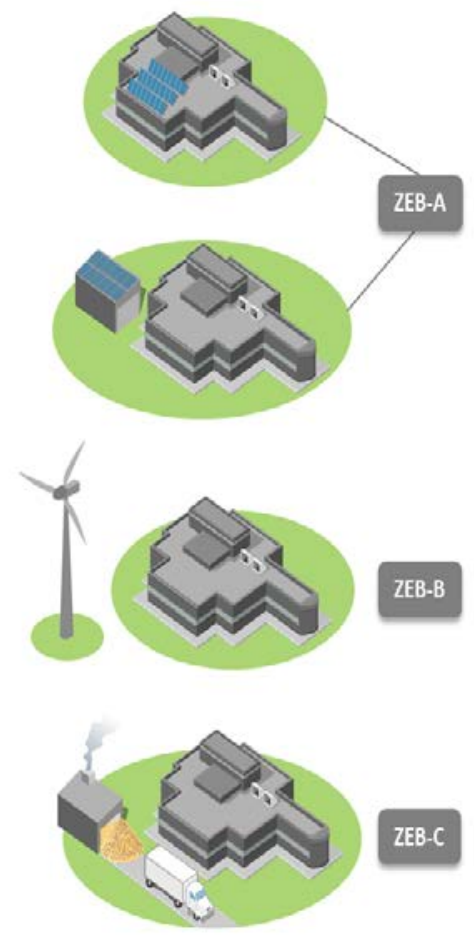
accessible to private markets. The Federal government's building infrastructure can demonstrate the innovative processes and emerging technologies that are not only making net-zero energy possible, but revealing and underscoring its desirability from both an economic and sustainability standpoint. Obstacles can be avoided in future planning by applying lessons learned to increase efficiency through proven energy savings and integrative techniques.

Each net-zero energy project that the Federal government successfully completes, whether it is a new building or a renovation, can serve as a set of valuable lessons for future projects. Given the aging Federal building stock, and the growing number of buildings eligible for historic preservation designation, the reconciliation of net-zero energy measures and sustainability goals with principles of renovation that

${ }^{10}$ Torcellini, P.; Pless, S.; Deru, M.; Crawley, D. (2006). Zero Energy Buildings: A Critical Look at the Definition. NREL/CP-550-39833. Golden, CO: National Renewable Energy Laboratory. Accessed September 22, 2014 : www.nrel.gov/docs/fy06osti/39833.pdf 
preserve and restore historic building components will be on the rise. Not surprisingly, integrating historic preservation requirements into net-zero design elements will assist the government in achieving multiple goals.

\subsection{Historic Preservation}

The National Historic Preservation Act of 1966 (NHPA) established the National Register of Historic Places, the National Historic Landmarks, and the State Historic Preservation Offices (SHPOs). The term "historic property" is defined in the NHPA as "any prehistoric or historic district, site, building, structure, or object included in, or eligible for inclusion on the National Register." As such, historic properties may include "artifacts, records, and

While preservationists use many tools in the designing and planning process for historic renovations to meet various regulations, a valuable asset can be archived photographs, like the one shown in Figure 3. remains which are related to such districts, sites, buildings, structures, or objects." Listing in the National Register is a formal recognition of a property's historical, architectural, or archeological significance, and provides opportunities for specific preservation incentives, which might include Federal preservation grants for planning and rehabilitation, Federal historic tax credits, preservation easements held by nonprofit organizations or government entities, building fire and life safety code alternatives, and potential state tax benefits and grant opportunities. ${ }^{11}$

Historic preservation involves the public and private sectors operating at local, state, and national levels. A key set of agencies and organizations administer and advocate for historic preservation within the public and private sectors:

- The National Park Service (NPS) is the principal Federal agency responsible for preservation programs and activities and administers the National Register of Historic Places. NPS has published a document titled Illustrated Guidelines on Sustainability for Rehabilitating Historic Buildings, ${ }^{12}$ which details guidelines for implementing a variety of sustainability measures on historic buildings, including solar photovoltaics (PV).

- In establishing a Federal policy for the preservation of cultural and historic resources, and creating the National Register, the NHPA also established an agency to support them - the Advisory Council on Historic Preservation (ACHP), whose primary role is to comment on Federal undertakings that affect historic properties, as required in Section 106 of the NHPA. The ACHP joins NPS as the other principal public preservation agency at the national level. The ACHP reviews and comments on Federal projects that affect properties determined eligible for listing on the National Register of Historic Places.

- SHPOs administer the resources and programs of the national historic preservation program for the benefit of citizens, communities, and organizations in each of the 50 states and territories. Tribal Historic Preservation Offices may assume any or all SHPO functions on tribal lands on behalf of a Federally recognized tribal community. Local historic preservation commissions

\footnotetext{
${ }^{11}$ Kandt A; Hotchkiss, E; Walker, A.; Buddenborg, J.; Lindberg, J (2011). Implementing Solar PV Projects on Historic Buildings and in Historic Districts. NREL/TP-7A40-51297, Golden, CO: National Renewable Energy Laboratory.

${ }^{12}$ Grimmer, A.; Hensley, J; Petrella, E.; Tepper, A; (2011).The Secretary of The Interior's Standards for Rehabilitation \& Illustrated Guidelines on Sustainability for Rehabilitating Historic Buildings. U.S. Department of the Interior, National Park Service, Technical Preservation Services. Accessed July 23, 2014: www.nps.gov/tps/standards/rehabilitation/sustainability-guidelines.pdf
} 
review projects under local preservation ordinances. Some of these local commissions are Certified Local Governments, which receive support from the NPS in partnership with SHPOs.

- The National Trust for Historic Preservation (National Trust) serves as the only national nonprofit dedicated to historic places. Statewide and local preservation nonprofit organizations provide advocacy, technical assistance, and education programs at the respective levels. National Trust programs combine historic preservation and economic development to promote downtown and neighborhood revitalization.

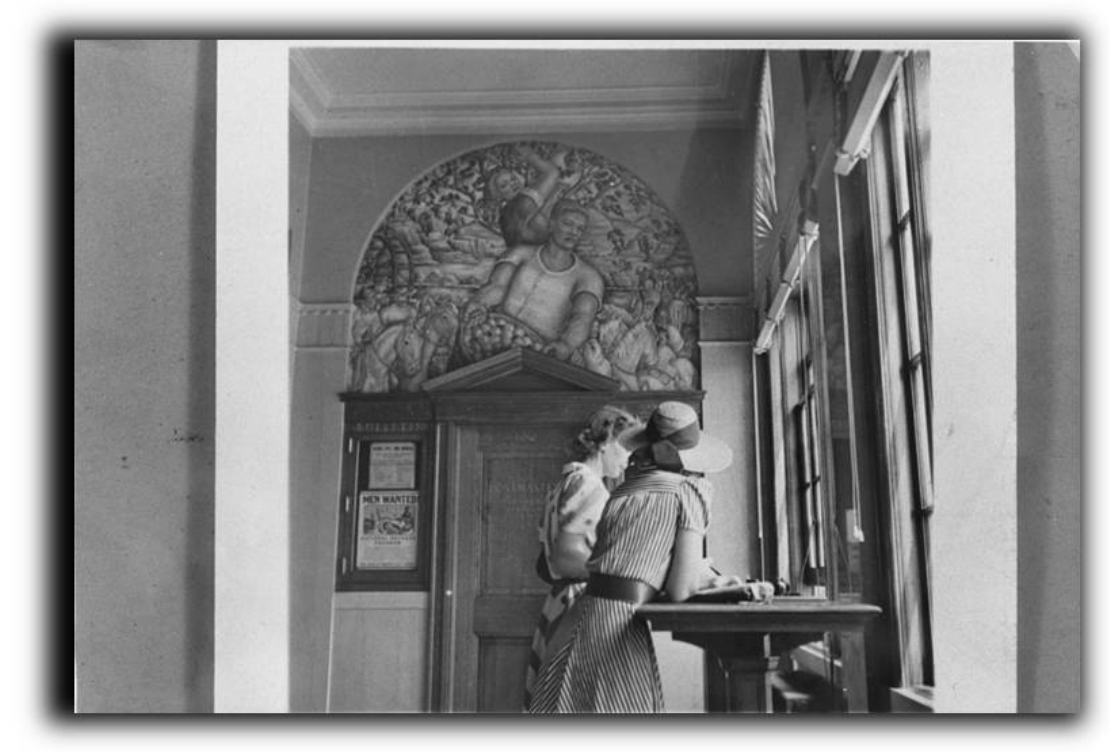

Figure 3. The Aspinall Courthouse lobby circa 1938

Source: GSA

The Federal, state, and local stakeholders operate within a set of guidelines for the preservation of historic properties known as the Secretary of the Interior's Standards for the Treatment of Historic Properties (Secretary's Standards), as well as with Federal, state, and local preservation laws. Only Federal agencies or projects with Federal involvement are required to use the Secretary's standards. The Secretary's standards are neither technical nor prescriptive, but are intended to promote responsible preservation practices and provide consistency to the preservation of historic materials and features of historic properties. The Secretary's Standards for Rehabilitation (hereafter, the "Secretary's Standards") are summarized below:

1. A property will be used as it was historically or be given a new use that requires minimal change to its distinctive materials, features, spaces, and spatial relationships.

2. The historic character of a property will be retained and preserved. The removal of distinctive materials or alteration of features, spaces, and spatial relationships that characterize a property will be avoided.

3. Each property will be recognized as a physical record of its time, place, and use. Changes that create a false sense of historical development, such as adding conjectural features or elements from other historic properties, will not be undertaken.

4. Changes to a property that have acquired historic significance in their own right will be retained and preserved. 
5. Distinctive materials, features, finishes, and construction techniques or examples of craftsmanship that characterize a property will be preserved.

6. Deteriorated historic features will be repaired rather than replaced. Where the severity of deterioration requires replacement of a distinctive feature, the new feature will match the old in design, color, texture, and, where possible, materials. Replacement of missing features will be substantiated by documentary and physical evidence.

7. Chemical or physical treatments, if appropriate, will be undertaken using the gentlest means possible. Treatments that cause damage to historic materials will not be used.

8. Archeological resources will be protected and preserved in place. If such resources must be disturbed, mitigation measures will be undertaken.

9. New additions, exterior alterations, or related new construction will not destroy historic materials, features, and spatial relationships that characterize the property. The new work shall be differentiated from the old and will be compatible with the historic materials, features, size, scale and proportion, and massing to protect the integrity of the property and its environment.

10. New additions and adjacent or related new construction will be undertaken in such a manner that, if removed in the future, the essential form and integrity of the historic property and its environment will be unimpaired.

\subsection{Net-Zero Design Complements Basic Design Principles of Historic Buildings} While the combination of executing a historic preservation and net-zero renovation may at first seem doubly daunting, these two concepts are actually closely aligned. The basic design principles used in the majority of historic buildings is nearly identical to those suggested by ASHRAE in the Advanced Energy Design Guides. The guides are a series of publications designed to provide recommendations for achieving energy savings over the minimum code requirements of Standard 90.1, the first step in the process toward achieving a net ZEB. The guides focus on different building types, but in general target passive design elements, such as insulation, maximizing daylighting, etc.

Energy design strategies suggested by the ASHRAE's Advanced Energy Design Guides include:

- Passive solar design

- High-performance building envelope (detailed consideration of glazing, insulation, and thermal breaks)

- Consideration of static building elements and landscape elements to assist in solar shading and natural ventilation

- [Utilizing] form with modular elements for maximum air flow efficiency.

In many instances historic building designs naturally integrated these concepts. For instance, buildings were already oriented to maximize daylighting and to provide as much thermal comfort as possible in the absence of electricity and central air conditioning. Often, historic buildings located in cold climates are south facing and have large windows on the south façade to allow for both daylighting and heat gain from the sun. Large thermal mass of building materials provides heat absorption and slower release of heat in winter months. In a sense, the principles of building design have come full circle as architects and engineers focus on maximizing the use of natural sources for lighting, heating/cooling and ventilation through design elements to reduce energy loads and reach net-zero operations. This same focus on maximizing the use of natural sources was essential to building design before the technological age. Thus, the goals of net ZEBs and historic buildings align well. 
The Aspinall Courthouse is a prime example of applying goals to meet sustainability, net-zero, and historic renovation goals. Post renovation, the Aspinall Courthouse is anticipated to:

- Use $40 \%$ less water than a comparable office building.

- Use $67 \%$ less energy than a minimally code-compliant building.

- Generate $100 \%$ of its energy onsite through use of a roof-mounted solar PV array.

The following sections summarize the Aspinall Courthouse renovation project, an example of a successful Federal historic property that achieved sustainability and net-zero energy goals, without compromise to the Secretary's Standards. 


\section{Aspinall Courthouse Project Background}

The Wayne Aspinall Federal Building is a three-story building with nearly 42,000 square feet of office space located in Grand Junction, Colorado. The building was constructed in 1918 and originally functioned as a post office and courthouse. A large extension was added in 1939, and the building was listed on the National Register of Historic Places in $1980 .{ }^{13}$ It currently houses nine Federal agencies. With funding from ARRA, GSA initiated a major renovation of the Aspinall Courthouse, focusing on historic preservation and energy efficiency upgrades. The project was completed in 2013.

\subsection{Building History}

In June 1910, the U.S. Congress authorized funds for construction of the first permanent post office in Grand Junction, Colorado. The building was originally completed in 1918 at a cost of $\$ 250,000$ and was designed by then-Supervising Architect of the Treasury, James Wetmore. Modifications were made by Wetmore's successor, Louis Simon.

The building is a rectangular steel and concrete structure with a limestone façade and parapet balustrade. The original design incorporated a second and third floor light well in the rear of the building. The dominant features of the building are the arched first-floor windows with sidelights, broad granite steps, and arcaded windows with

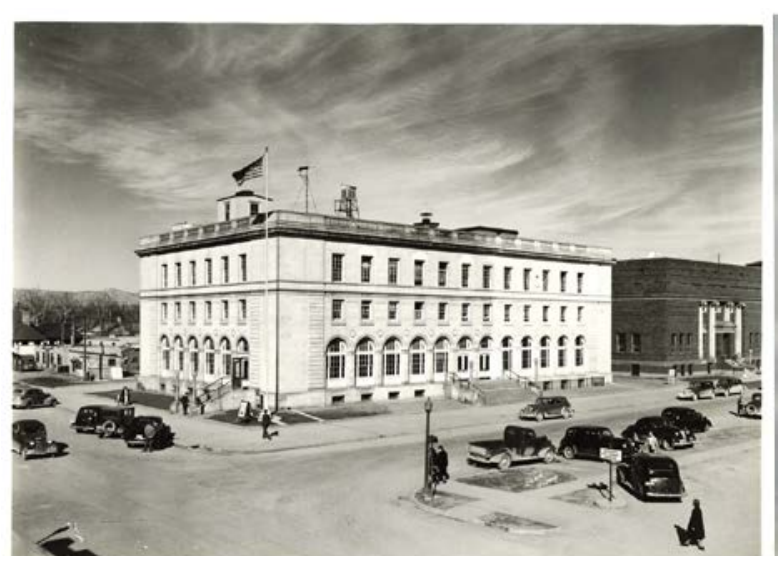

Figure 4. Aspinall Courthouse, circa 1938 Source: GSA carved capitals. The building is architecturally significant as an example of the Second Renaissance Revival-style government building.

The building has undergone major changes during its lifetime. As new agencies began leasing space within the building, spaces were converted to fit the needs of the tenant agencies. The result was a conversion of the prominent public spaces into new office space, as commonly occurs with historic buildings: occupancy needs change, over time.

An expansion of the building to the east, as part of the Works Project Administration, was completed in 1938. In the mid 1960's, the U.S. Postal Service moved out of the building into an adjacent free standing structure, and GSA took possession of the building, leasing out the available space created by the U.S. Postal Service to other Federal agencies. Today, the total floor area of the building is nearly 42,000 square feet, although only 21,000 square feet are occupied.

During the course of decades of modifications, the public lobby, which once spanned most of the length of the south façade (nearly 40 feet from the elevator to the historic southwest staircase), was reduced to a modest 15 -foot $\times 15$-foot entry vestibule. A decision to locate office space along the perimeter of the building's first floor resulted in small corridors that were cut off from natural daylight, and inhibited overall traffic flow.

\footnotetext{
${ }^{13}$ The Aspinall Courthouse is listed as the U.S. Post Office at 400 Rood Ave, Grand Junction, CO on the National Register of Historic Places. Accessed February 26, 2014: http://www.nps.gov/nr/research/.
} 


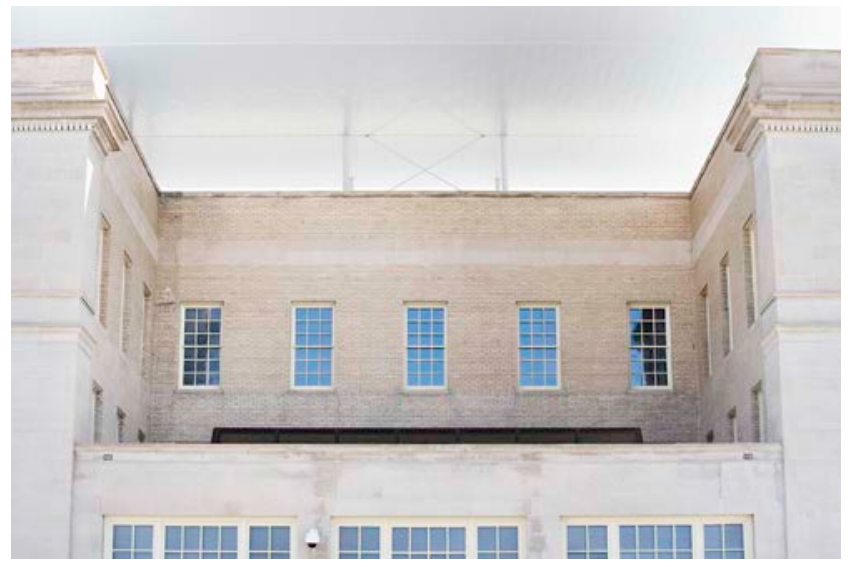

Figure 5. Aspinall Courthouse light well in the rear of the building, circa 2012 Source: GSA

The original building design did not include HVAC systems. An HVAC system was introduced into the building in the 1960s, along with upgraded electrical systems. Dropped acoustic ceiling tiles were installed to mask the new ductwork, lowering the ceiling height and reducing the volume of internal airflow. The original lighting fixtures were replaced with ceiling-mounted fixtures and wall sconces.

In 1972, the building was rededicated. It was named the Wayne N. Aspinall Federal Building and United States Courthouse, after Democratic Congressman Wayne N. Aspinall, who served in the U.S. House of Representatives from 19491973 and hailed from Colorado's Western Slope. In 1980, the Aspinall building was listed on the National Register of Historic Places. The building currently hosts offices and courthouses for U.S. Courts, U.S. Probation, U.S. Marshals, the U.S. Army Corps of Engineers, one of Colorado's state Senators, the Federal Bureau of Investigation, U.S. Attorneys, the Internal Revenue Service, and GSA.

In 2010, GSA considered disposing of the property because the building needed extensive repairs and renovation that GSA could not hope to cover from existing or expected appropriations. As a 1918 building with almost 42,000 square feet of office space, the Aspinall Courthouse needed major updates and repairs to address a long list of deficiencies, including poor lighting, windows that had been covered up, low-hanging ceilings, and poor ventilation and indoor air quality.

Many of the building's significant systems had reached the end of their useful life, notably, the mechanical and electrical systems, the elevators, and the roofing materials. If GSA were to renovate the building, it would have to ensure, at a minimum, upgrades or replacements for these critical systems. Because the building had been listed on the National Register of Historic Places, the modernization would have to comply with Section 106 of the NHPA of 1966 for rehabilitation of historic structures, as described in Section 1.2 of this summary. Section 106 of the NHPA requires Federal agencies to assess the effects of their undertakings on historic properties and to provide the Advisory Council on Historic Preservation with the opportunity to comment on such undertakings, if there is a potential to affect historic properties. GSA considered disposal of the historic property.

Disposal was averted when Congress enacted ARRA, appropriating funding for real property upgrades that ultimately enabled GSA was able to keep the Aspinall Courthouse from closing its doors. Instead of preparing for disposal of the building, GSA began to outline an unprecedented plan to carry out an extensive renovation project combining net-zero energy and historic renovation goals. Uniquely, in this single but significant undertaking, GSA was doing its part to preserve the future by restoring the past.

The GSA used ARRA funding to reduce energy consumption and incorporate sustainable design into projects on a national scale. A variety of contracting mechanisms were used to complete these projects, but for the Aspinall renovation, GSA chose a design-build contract, which is discussed in a following section. The design-build goals of the renovation centered on full mechanical, electrical, and plumbing replacement and used a life cycle cost analysis with a goal of reaching $30 \%$ better performance than ASHRAE Standard 90.1-1999. The project budget totaled \$15 million in ARRA funding and included 
design build, construction management and commissioning agent. ${ }^{14}$ The cost of the renovation was about $\$ 360 / \mathrm{ft}^{2}$. All implemented net-zero energy measures had a positive life cycle cost.

\subsection{Project Goals}

GSA's Minimum Performance Criteria for Recovery Projects for new construction and major renovations set parameters to comply with the Guiding Principles ${ }^{15}$ as well as third-party green building certification requirements. GSA identified renovation goals for the Aspinall Courthouse, which centered on sustainability principles and energy use. Aware that the renovation had to comply with historic preservation standards as well as meet net-zero energy goals, GSA established the following list of objectives for the renovation:

1. Realization of a net ZEB (aligning with government requirements for net-zero and energy independence by 2030)

2. U.S. Green Building Council Leadership in Leadership in Energy and Environmental Design "Platinum" certification

3. Improved indoor environmental quality and thermal comfort

4. Water use reduction $(\sim 40 \%)$

5. Use of sustainable construction practices

6. Effective use of technology while preserving historic attributes of the building.

The sixth objective was crucial to the success of the historic renovation because, paradoxically, the key to historic preservation was careful integration of innovative technology with principles of sustainable design. In service to this objective, GSA decided to focus the Aspinall Courthouse renovation on preserving specific architectural elements of the building and re-establishing formerly prominent architectural features and spatial relationships, to ensure full adherence to the Secretary's Standards.

\footnotetext{
${ }^{14}$ Design-build is a construction industry method used to deliver a project using a single point of responsibility contract to minimize risks for the project owner and reduce the schedule of a project.

${ }^{15}$ http://www.wbdg.org/sustainableEO
} 


\section{Aspinall Courthouse Renovation Process}

The success of the Aspinall Courthouse renovation is due, in part, to the foresight of the planning team, which established its goals early in the process. This section details that process and the goals achieved.

\subsection{Design-Build Contracting}

The unique combination of net-zero design considerations with historic preservation goals required an extensive and ongoing planning and problem-solving process during the design stage. GSA selected and applied a design-build process, ${ }^{16}$ targeting net-zero performance first. Although historic preservation would be addressed specifically during the NHPA Section 106 review process, GSA's planning team had to consider in the design phase how the project would comply with the Secretary's Standards in order to ensure a successful outcome during Section 106 review.

\subsubsection{Selecting a Design Team}

Selecting a team for a renovation project with net-zero and historic preservation goals is the most important upfront decision. Essential to success is a team that identifies goals, develops and demonstrates an effective strategy to achieve those goals, can review critical points of the design process, and ultimately reaches the identified goals.

Typically, for government construction projects, the first steps are a request for qualifications and a request for proposals. A request for qualifications is an opportunity for the building owner and project lead to request specific qualifications from design-build teams. The Aspinall Courthouse renovation followed the two-step procurement process consisting of a request for qualifications and a request for proposals stage. The proposal phase required bidders to address minimum performance criteria and encouraged bidders to provide innovative design options to expand on energy goals. Bidders were invited to suggest ways in which modern, high-performing technologies could be integrated into the historic structure.

The design-build contract offered benefits to a project focused on energy enhancements by integrating the entire project team at the outset of the project. Early design meetings were structured to ensure the presence of the owner, builder, architects, engineers, commissioning agent, and construction manager during this critical phase of project development. It was during these meetings that the team was able to establish net-zero energy and historic preservation goals for the project.

\subsubsection{Identifying Risks}

The team identified risks to each party at the start of the project and throughout its execution. For instance, shared risk among all participants ensured accountability for goal achievement. The contractor bore risks of its acceptance of a firm-fixed price contract based on a program of requirements, scope of work, agency design guidelines, policies and the design-build proposal. The risks to the design-builder related to the uncertainty presented by the innovative renovation project, where the contract required the design-builder to maintain pricing through design development based on the contract documents and through construction. For GSA's part, as the owner, it bore the risk that the conceptual design (which had been proposed at time of award) could be altered significantly if the NHPA Section 106 historic preservation reviews were not favorable.

\footnotetext{
${ }^{16}$ Design-build is a construction process that allows the design and construction services to be contracted by a single entity, often simplifying contractual obligations and expediting the construction process.
} 
Significant to the aggressive energy goals set by the planning team was the additional risk that decisions of the SHPO, Grand Junction Historic Preservation Board, and the ACHP could adversely affect the Aspinall Courthouse's energy performance. The project's design direction sprang from the design-build proposal, and the historic preservation reviews could only take place post-award. Therefore, ongoing discrete changes to the design could occur mid-project through change order requests with the contractor, and cumulatively could compromise the general design intent, including its energy and sustainability goals. Finally, an overarching challenge to the entire team was undertaking a construction project in an occupied historic building, where construction crews could encounter unforeseen conditions and potential schedule impacts.

In light of the unusual risks presented by the Aspinall project, early collaboration was essential. Overall, the design-build approach supported collaboration among entire project team, enabling it to consider problems and solutions, and identify opportunities that may not otherwise have emerged. The integrated team approach enhanced the project's energy and preservation goals. In retrospect, the design-build contracting method conferred significant advantages on this unique and significant project, allowing broader than average reviews of systems, constructability, cost benefits and improved energy performance, and perhaps above all, the exchange of ideas that elevated common interests over the positions of the parties.

\subsection{Principles of Net-Zero Design and Operations}

For any structure to achieve net-zero, energy loads must be analyzed and minimized. A building's energy use is typically determined by four main systems: HVAC, lighting; the building envelope, and plug loads. As such, the design process involved four steps:

1. Optimize the building envelope.

2. Reduce internal loads.

3. Design high-efficiency systems.

4. Match building energy load to on-site renewable energy.

Extensive energy modeling is typically conducted to analyze the impacts of various measures on a building's energy performance. Modelers develop the geometry of the building, import weather data for the location of the building, assign equipment types and efficiencies, and then develop various scenarios relating to modifications within building systems. For example, modelers may analyze the impacts of different lighting systems or plug loads, adding specific types of insulation (and assigning different Rvalues), different window systems (and assigning different U-values), and/or installing renewable energy systems. The development of various scenarios allowed the design team to determine the best strategies for minimizing energy loads within the project's parameters. In the case of the Aspinall Courthouse, historic preservation strategies influenced energy strategies.

The energy modelers for the Aspinall Courthouse used a 10-year weather average for Grand Junction and included plug load data from the building's occupants pre-construction. The model included optimal system performance criteria, such as indoor set points of $75^{\circ} \mathrm{F}$ for cooling, $69^{\circ} \mathrm{F}$ for heating, set hours for operation, averaged hours of direct sunlight, and impact of lighting system design. Table 1 shows the modeled energy consumption compared to energy production. The modeled performance illustrates how a building can accomplish net-zero energy use: over the course of a year, the building's renewable energy systems can produce more energy than the building consumes annually. An example of the model rendering is shown in Figure 6. 
Table 1. Modeled Monthly Energy Consumption and Production

\begin{tabular}{|c|c|c|c|}
\hline & $\begin{array}{c}\text { Estimated } \\
\text { Monthly } \\
\text { Electricity } \\
\text { Consumption } \\
\text { (kWh) }\end{array}$ & $\begin{array}{c}\text { PV Production } \\
\text { Monthly Total } \\
\text { (kWh) }\end{array}$ & $\begin{array}{c}\text { Total Production } \\
\text { Beyond } \\
\text { Estimated Use } \\
\text { (kWh) }\end{array}$ \\
\hline January & 13,998 & 7,998 & $-6,000$ \\
\hline February & 11,371 & 10,139 & $-1,232$ \\
\hline March & 12,063 & 14,504 & $+2,441$ \\
\hline April & 10,853 & 17,504 & $+6,651$ \\
\hline May & 13,804 & 20,559 & $+6,755$ \\
\hline June & 16,577 & 21,414 & $+4,837$ \\
\hline July & 17,270 & 20,445 & $+3,175$ \\
\hline August & 17,571 & 18,813 & $+1,242$ \\
\hline September & 14,235 & 15,461 & $+1,226$ \\
\hline October & 12,342 & 11,995 & -347 \\
\hline November & 12,195 & 8,296 & $-3,899$ \\
\hline December & 13,277 & 6,809 & $-6,468$ \\
\hline Annual Totals & $165,556 \mathrm{kWh}$ & $173,897 \mathrm{kWh}$ & $+8,381 \mathrm{kWh}$ \\
\hline
\end{tabular}

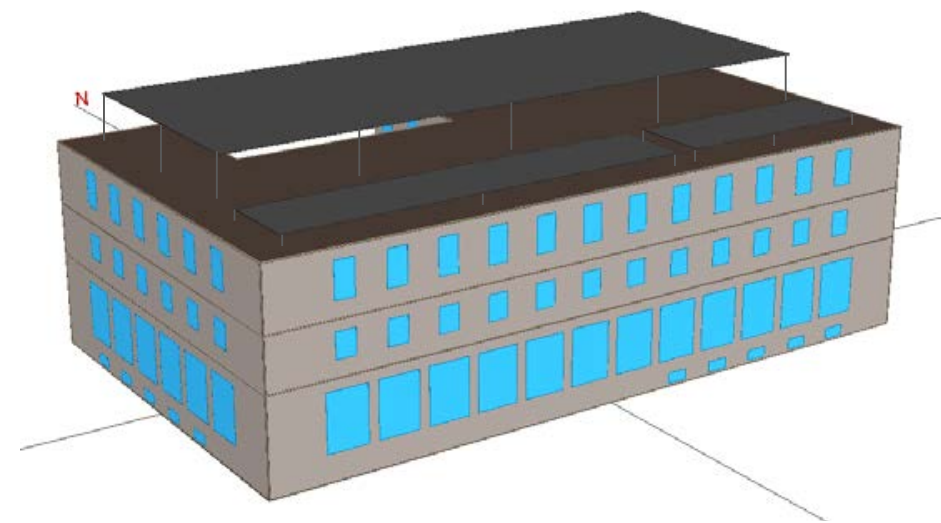

Figure 6. A modeled rendering of the Aspinall Courthouse façade Source: Jimmy Salasovich, NREL

Constructing a building designed for net-zero energy consumption is just the first step. After construction, even the most energy-efficient building can waste plenty of energy if it is not operated efficiently. Efficient operations include monitoring and verification $(\mathrm{M} \& \mathrm{~V})$, which is key to realization of net-zero energy goals.

Usually, in the absence of a cohesive, effective net-zero operations plan that includes M\&V, energy goals can be lost as systems are pieced together through negotiations with contractors, manufacturers, and operations managers. $\mathrm{M} \& \mathrm{~V}$ principally includes comprehensive monitoring of the building systems, established energy consumption targets and data collection, and defined roles and responsibilities of facility managers. 
Two factors are key to a successful M\&V plan: (1) the owner must have an active role in energy performance; and (2) the project delivery team must retain a strong role during postcommissioning through the first year of the building's operation. Building operators may require training in using monitoring programs and building systems. Interaction with and obtaining feedback from occupants is important to determine where system operations need to be modified or fine-tuned. An effective net-zero operations plan includes the following steps and considerations to ensure net-zero energy goals are met and maintained:

- Identify key energy decision-makers in the facility and list them in the plan, along with their roles and responsibilities.

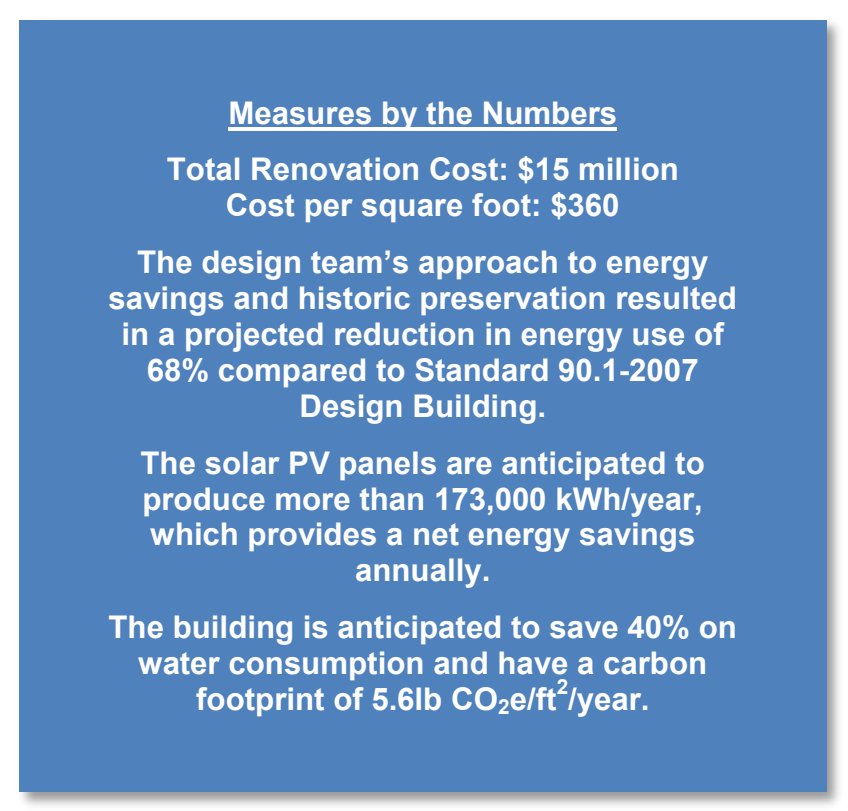

- Ensure the design and construction process delivers a useful expectation/prediction of absolute energy use.

- Use warranties, commissioning, and/or incentive programs to address efficiency-related strategies.

- Utilize funding streams, such as utility rebate funds, to reinvest in implementing new (and enhancing existing) efficiency-related strategies.

- Educate building operators on efficiency strategies.

- Implement strategies to address: glare from natural daylighting, lighting adjustments, plug load selection and operations, data center performance tracking, useful metering for real-time end-use budget tracking, HVAC controls and sequence of operations, night and weekend load management, new loads or occupant systems management, etc.

- Evaluate performance and assess goals, then modify strategies to improve efficiency and add renewable energy technologies, where needed. Scheduling regular strategic meetings will assist in keeping this evaluation on track.

- Occupant engagement and education, public relations and tours.

\subsection{Implementation of Renovation Measures}

The Aspinall Courthouse renovation project established the goal of becoming GSA's first net ZEB on the National Register of Historic Places. The Aspinall Courthouse renovation consisted of no fewer than 12 separate renovation measures. Some measures were conducted to improve the energy performance of the building, some measures were intended to restore historic architectural features, and some measures addressed both areas. The energy efficiency and net-zero energy features were designed to meet Leadership in Energy \& Environmental Design Platinum certification (http://www.usgbc.org/certguide/commercial) while historic spaces and finishes within the public and agency areas were restored.

\subsection{Historical Measures}

Often, with historic properties, the original features have been covered by previous renovation projects, only to be revealed in future work. In 1965, the U.S. Postal Service vacated the Aspinall Courthouse 
building; GSA, after taking ownership of the building, modified the two main entrances, first-floor post office area, and elevator lobbies for the building tenants.

During the ARRA-funded renovation project, some of the renovation measures restored the courthouse's original historic features and spatial relationships, while improving efficiency. One such measure was the removal of the false ceilings that had been installed; this restored the original spatial relationship between the tenants and the building and enabled the full advantage of the building's original passive lighting features.

The net-zero energy renovation project restored many of the Aspinall Courthouse's original features:

- The main lobby was extended from the small entry vestibule to its original size.

- The three-floor height historic curved stairwell was reconnected with the lobby.

- Original arched windows, interior arched colonnade, decorative column capitals, marble-bordered terrazzo floor, and other historic elements were re-exposed to be visible from the lobby.

- Wood features were restored, such as the flooring in the lobbies and corridors, and the original wood paneled doors.

- Arched windows that were hidden behind dropped ceilings were revealed again.

- Original doors, walls, and ceilings were repaired and refinished.

- The original skylight in the post office workroom was restored to provide increased daylight.

By repairing and refinishing the existing doors, walls, and ceilings, the project team was able to reduce the amount of project waste, avoiding hauling, demolition and landfill costs that would be incurred in conventional renovation projects.

\subsubsection{Efficiency Measures}

Preserving historic features can have a positive environmental impact. For example, reusing an existing building extends the life of the resources that were used to construct the building in the first place, and reduces demolition waste. For Aspinall, all the measures that relate specifically to energy efficiency or the overall netzero energy design of the building were considered with

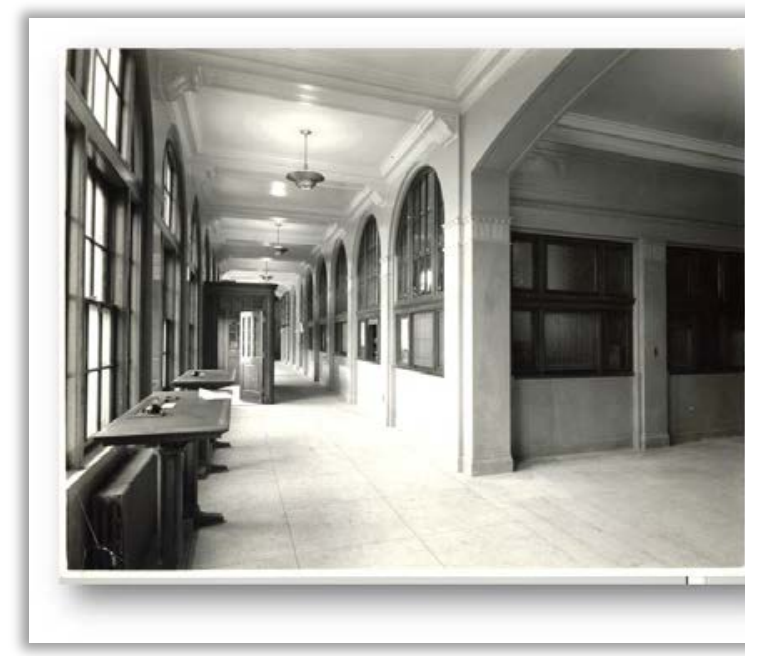

Figure 7. Lobby in 1938 Source: GSA

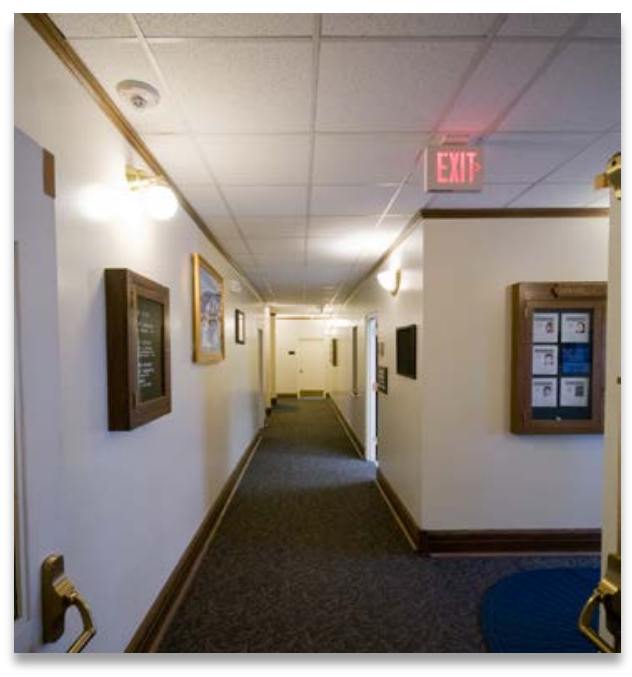

Figure 8. Lobby pre-construction (2010) Source: GSA 
historic preservation in mind. However, as one might expect, not all energy savings measures could be completely isolated from the historic preservation features of the project. The design team took special care with their incorporation into the renovation design.

Energy efficiency measures included:

\section{Building Envelope}

- Installing spray foam insulation (with a thermal resistance of R-10) to the masonry walls, reducing overall building energy consumption by $11 \%$.

- Installing 10-in. rigid insulation on the roof (average thermal resistance of R-35), to reduce heat loss and heat gain. Reducing heat loss and heat gain led to down-sizing the heating and cooling equipment compared to the pre-renovation system sizes, which is more efficient, reduces the use of ozone-depleting refrigerants and saves on installation and operational costs.

- Adding a white colored roof membrane, also called a 'cool roof', to reduce solar gain and air-conditioning loads. Cool roofs are thought to reduce urban heat island effects and reduce air conditioning needs. ${ }^{17}$

- In order to preserve the historic wood-framed, single-paned windows, the project team installed new storm panels with highperformance UV control film in lieu of doublepaned replacement windows. This measure reduced the U-value from 1.04 to 0.5 , and the solar heat gain coefficient from 0.86 to 0.53 .

\section{Electrical and Mechanical Systems}

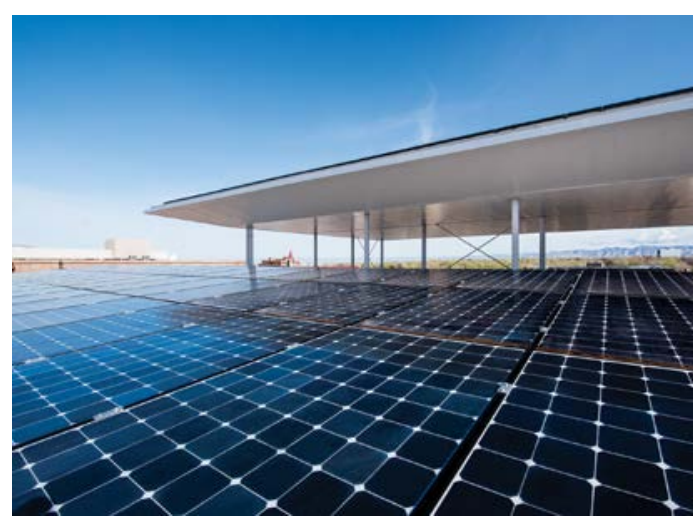

Figure 9. 123-kW PV roof-mounted system Source: Kevin Reeves, GSA, 2013

- Replacing outdated mechanical and electrical systems with highly efficient technologies, including a water-source variable refrigerant flow HVAC system (which reduced the need for ozone-depleting refrigerants).

- Replacing inefficient lighting systems with LED systems or T-8 lighting to reduce energy consumption, cooling load, and maintenance.

- Installing advanced metering and wireless controls for lighting and HVAC system control, including solar powered devices, which reduce the need for wiring, thus reducing the impact to the historic structure. Workstations are located close to windows for natural daylighting.

- Perimeter light fixtures have been zoned separately and equipped with dimmable controls to dim or switch off electric lights as natural daylight increases, thus preventing overlit areas and saving energy.

- Pairing the high-efficiency HVAC system with a geothermal exchange system to filter and condition air for comfortable cooling and heating year-round. (See geothermal exchange system under clean energy solutions).

${ }^{17}$ DOE states that a cool roof can reduce a single story building's air conditioning use by $15 \%$; http://energy.gov/sites/prod/files/guide to cool_roofs.pdf 


\section{Water Systems}

- Replacing high-volume plumbing fixtures with low-flow, EPA WaterSense rated plumbing fixtures, which are estimated to reduce water use by approximately $40 \%$ less than a typical building.

\section{Clean Energy Solutions}

- Installing a solar photovoltaic canopy on the roof (385 panels generating $123 \mathrm{~kW}$ of electricity) to produce an estimated $173,897 \mathrm{kWh}$ per year. ${ }^{18}$

- Installing a geothermal exchange system (with 32 ground-source wells, at 475 feet deep) to allow the building to reject heat into the ground during the warm months or absorb heat from the ground in the cooler months. This system is called a geothermal exchange system because it provides both cooling and heating using stable ground temperatures throughout the year.

\section{Alternative Transportation Modes}

- Fuel-efficient vehicle parking spaces have been designated and a bicycle rack installed to encourage alternative modes of transportation that reduce fuel use.

\subsubsection{When Old Meets New}

The Aspinall Courthouse renovation is an example of modifying historic buildings to improve energy performance, without impacting the historical integrity of the building structure. The following examples of measures that include introducing new technology while maintaining the historic features highlight the success of the Aspinall Courthouse project.

\section{Building Envelope Improvements}

The design team discerned an innovative way to increase the R-value of the building envelope without damaging the integrity of historic plaster walls and window casings. The team took a thermal infrared image of

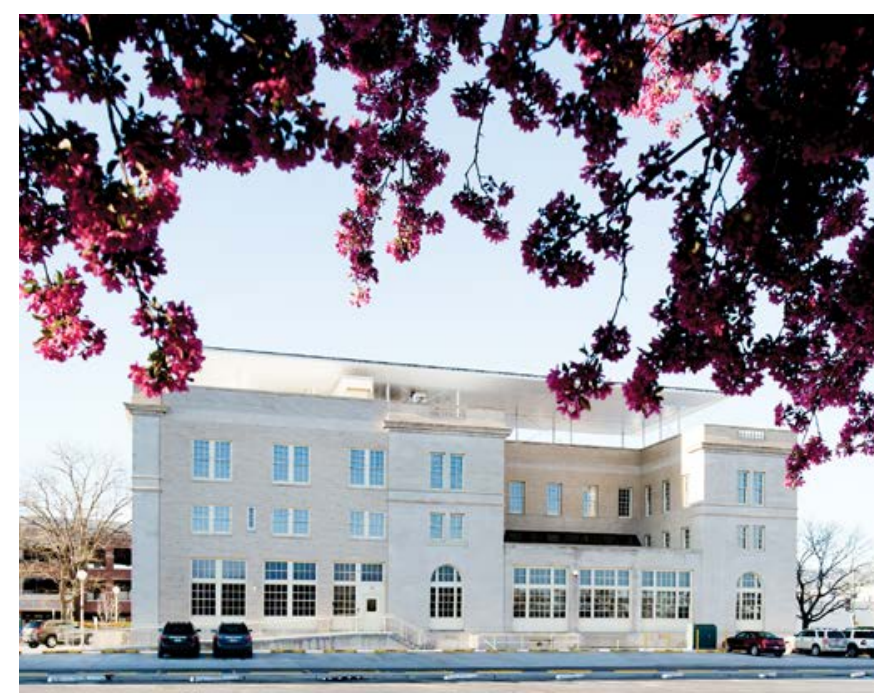

Figure 10. Aspinall Courthouse, north elevation, postconstruction 2013

Source: Kevin Reeves, GSA the building early in the project to determine where heat was being transmitted through the building envelope. The team visually noted heat loss through the building's leaky envelope, and determined that a viable measure to reduce heat loss was to increase the R-value of the walls. The walls, as mentioned previously, are comprised of an exterior limestone façade, backed with a terra cotta block, metal lath, and an interior plaster wall finish. Changing the plane of the interior plaster would negatively impact other historical components of the interior, such as window casings. The design team decided to remove the plaster wall, metal lath, and the terra cotta block to create a wall cavity that could be filled with 2" of spray foam insulation throughout the building's perimeter to increase the R-value of the wall to R-10. An analysis for dew point changes was conducted to determine whether an increase in dewpoint would occur, causing condensate and mold issues. The team determined the changes to be negligent, so the measure was completed, saving $11 \%$ in energy.

\footnotetext{
${ }^{18}$ Based on 385 panels rated at 320W each (SunPower E19 modules).
} 
The following table illustrates the baseline design of the Aspinall Courthouse compared to the proposed design for improved efficiency. The proposed case shows the modeled energy performance. Windows are not included in the table, but had a final $U$-value of 0.5 , a solar heat gain coefficient of 0.53 and a $45 \%$ visual transmittance.

Table 2. Baseline Versus Proposed Design Elements

\begin{tabular}{|c|c|c|c|c|c|c|}
\hline \multirow{2}{*}{$\begin{array}{l}\text { Model Input } \\
\text { Parameter or } \\
\text { Energy } \\
\text { Efficiency } \\
\text { Measure }\end{array}$} & \multicolumn{3}{|c|}{ Baseline Case } & \multicolumn{3}{|c|}{$\begin{array}{c}\text { Proposed Case } \\
\text { (Improved Efficiency) }\end{array}$} \\
\hline & Description & $\begin{array}{l}\text { Insulation R- } \\
\text { Value }\end{array}$ & $\begin{array}{l}\text { Assembly } \\
\text { U-Factorl } \\
\text { C-Factorl } \\
\text { F-Factor }\end{array}$ & Description & $\begin{array}{l}\text { Insulation R- } \\
\text { Value }\end{array}$ & $\begin{array}{c}\text { Assembly } \\
\text { U-Factorl } \\
\text { C-Factor/ } \\
\text { F-Factor }\end{array}$ \\
\hline Roofs & $\begin{array}{l}\text { Insulation above } \\
\text { deck (exist) }\end{array}$ & R-15 & 0.06 & $\begin{array}{l}\text { Insulation } \\
\text { above deck }\end{array}$ & R-35 & 0.03 \\
\hline Roof SRI & $\begin{array}{c}\text { Membrane } \\
\text { (exist), SRI = } 30\end{array}$ & & & $\begin{array}{c}\text { TPO } \\
\text { membrane, } \\
\text { SRC=78 }\end{array}$ & & \\
\hline $\begin{array}{l}\text { Walls Above } \\
\text { Grade }\end{array}$ & Existing masonry & None & 0.183 & $\begin{array}{l}\text { Existing + 2-in } \\
\text { spray foam }\end{array}$ & $\mathrm{R}-13$ & 0.075 \\
\hline $\begin{array}{l}\text { Walls Below } \\
\text { Grade }\end{array}$ & Existing masonry & None & 0.259 & $\begin{array}{l}\text { Existing + 2-in } \\
\text { spray foam }\end{array}$ & R-13 & 0.075 \\
\hline $\begin{array}{l}\text { Slab-on- } \\
\text { Grade Floors }\end{array}$ & Existing masonry & None & $F-0.73$ & $\begin{array}{l}\text { Existing } \\
\text { masonry }\end{array}$ & None & $F-0.73$ \\
\hline $\begin{array}{l}\text { Opaque } \\
\text { Doors }\end{array}$ & Swinging & & U-0.7 & Swinging & & U-0.7 \\
\hline
\end{tabular}

\section{A High-Efficiency HVAC System}

The design team chose the variable refrigerant flow (VRF) fan coil system was chosen for the project because for it is both highly efficient and because it requires minimal ductwork, which meant fewer intrusions into the historic design of the building. In the water-based system, the fan coils are connected to the geothermal heat pump system. The variable flow system allows greater energy savings than a traditional fixed-flow system because the system can ramp up or down depending on the season and occupancy demands. The heat pump rejects heat through the water source or absorbs heat from the ground. The vertical geothermal wells are located in the parking areas and city alleyways adjacent to the building. ${ }^{19}$ The system overall is far more efficient than typical HVAC systems (geothermal heat pumps and exchange systems are typically $45 \%$ more efficient than traditional HVAC systems) and reduced the visual impact on the historic features of the building. ${ }^{20}$

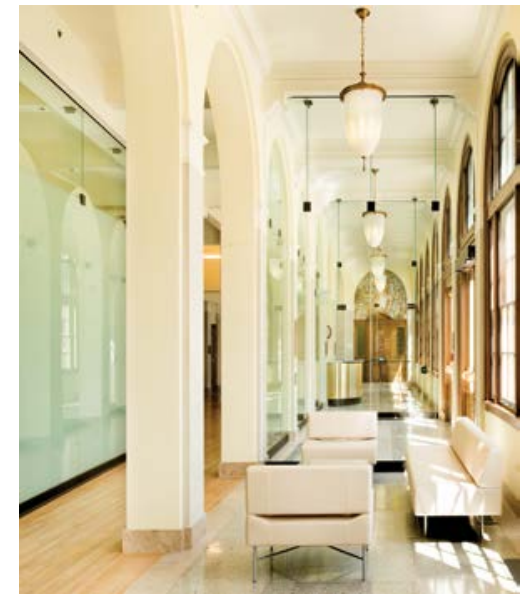

Figure 11. Lobby post-construction in 2013

Source: Kevin Reeves, GSA

\footnotetext{
${ }^{19}$ The City of Grand Junction provided the alley space for 12 of the 32 wells due to the building's existing site constraints.

${ }^{20}$ www.energystar.gov/products/certified-products/detail/heat-pumps-geothermal
} 


\section{Efficient Lighting}

The historic exterior stair lights and the wagon wheel bronze fixtures in the courtroom were the only remaining lights from the 1938 renovation. These fixtures were re-lamped with LED lamps, reducing energy consumption as well as cooling loads and reducing fixture maintenance. The lobby lighting was recreated using the 1918 teardrop light fixtures as inspiration, as shown in Figure 11. These lighting fixtures, along with all of the building's lighting fixtures within 15 feet of the windows, apply daylighting controls.

\section{Controls and Metering}

The building renovation incorporated advanced metering to allow real-time energy and water use monitoring, which helps inform those who manage the building's utility costs. These data support decision-making processes and make instantaneous control of building systems for optimum performance possible.

Newly installed occupancy and daylight sensors ensure that no energy is wasted lighting unoccupied spaces. The majority of these are wireless to minimize intrusion on historic plaster walls and ceilings. Additionally, many of the wireless controls are solar powered, reducing energy consumption even more. Daylight sensors dim and turn off lighting fixtures installed near windows when the light levels are adequate from natural daylight. In common areas lighting switches on manually, but turns off automatically, after a designated amount of time. Occupants may also turn lights off manually. Lighting in public spaces is set to 1 footcandle for safety lighting, when the space it not occupied from 6:00 a.m. to 6:00 p.m. After 6:00 p.m., public space lighting automatically switches off if sensors do not detect occupancy.

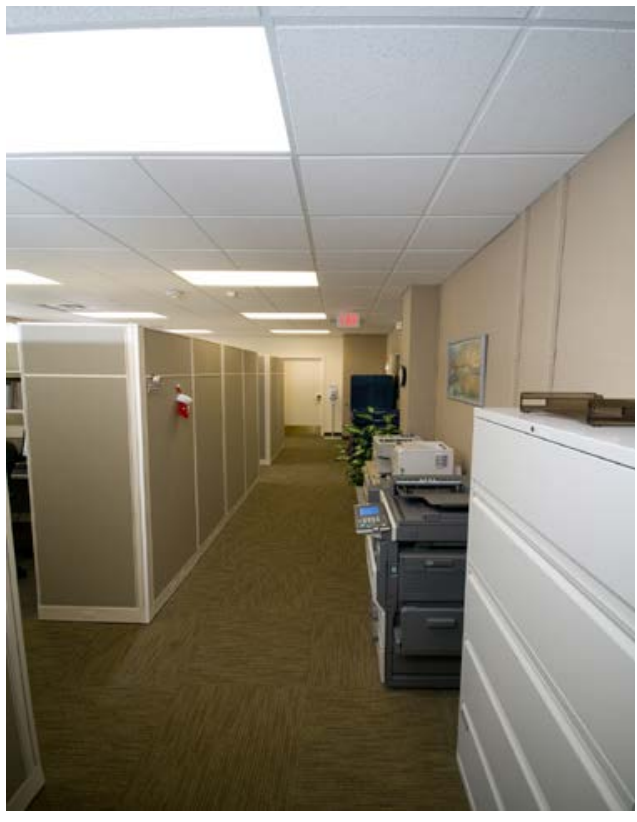

Figure 12. Tenant space pre-construction, 2010 Source: Kevin Reeves, GSA

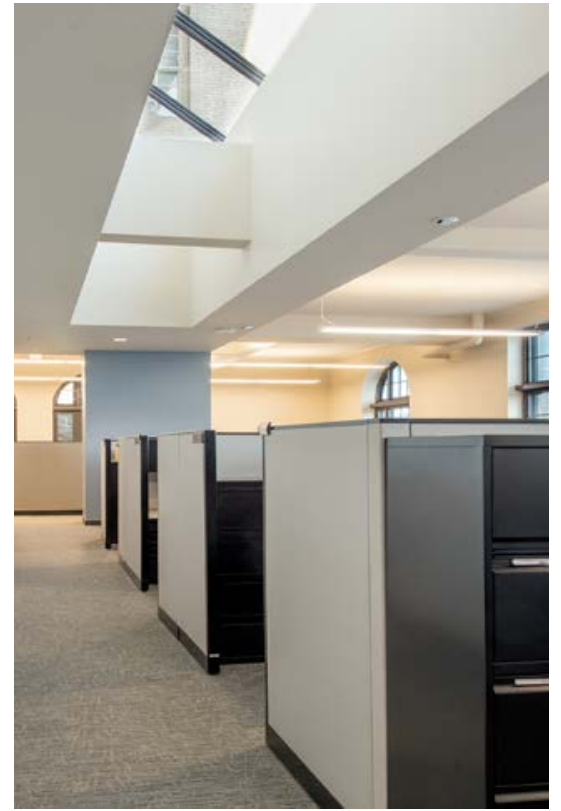

Figure 13. Tenant space postconstruction, 2013 Source: GSA

In the Aspinall building, many aspects of lighting and HVAC are driven by automatic detection of building occupancy. The same wireless controls that detect occupancy to regulate lighting are connected to the HVAC systems, which also detect $\mathrm{CO}_{2}$ levels. An outside air monitoring unit provides fresh air to the building depending on the indoor $\mathrm{CO}_{2}$ levels, which increase with occupancy. Each tenant space is 
zoned separately, permitting greater occupancy-driven control over conditioning of spaces, as well as by activities specific to tenants. Energy and water consumption data is gathered, stored and displayed for the entire building. The before-and-after images in Figures 12 and 13 illustrate the use of natural daylight and more efficient lighting fixtures in the tenant spaces.

To better manage plug loads, the project team incorporated two measures. Each cubicle is equipped with desk-mounted occupancy sensors wired to smart plug strips, which power down equipment after the workstation becomes "inactive". Certain plugs in the strips can be used for equipment that needs to stay on at all times, enabling the occupant to control his or her power needs. The second measure is the installation of a load shedding device in many convenience outlets throughout the building. The load shedding device is scheduled to turn on in the mornings and off in the evenings and over the weekends. These devices eliminate phantom power or ghost loads from equipment plugged into them. A green sticker affixed to the outlets indicates which are equipped with the load shedding devices.

\subsection{Innovative Solutions}

The project team encountered a number of challenges during the design, modeling, and execution of the renovation project. The challenges are identified in this case study to illustrate what may be common problems in future similar projects, and the ways GSA and the design-build team were able to overcome them. Alignment of the net-zero operations goal and historic preservation requirements were addressed and the alignment process was based largely on negotiations with the SHPO. The GSA Center for Historic Building provided feedback, as well. The largest change resulting from the NHPA Section 106 review process was the modification of the PV system design.

\subsubsection{Solar PV}

In order to accommodate the Secretary's Standards, the project team designed the PV canopy as an "additive" structure so that it could be removed without adverse impact to the property after 25 years, when the panels either reached the end of their useful life or the advancements in PV technology had increased efficiency to the point that less surface area would be required to produce the same amount of energy (i.e., a smaller system could be installed to produce the same amount of energy). This design accommodated the principle of the Secretary's Standards requiring preservation of the essential form and integrity of the historic property upon removal of additional or adjacent structures.

However, during the NHPA Section 106 review, another of the Secretary's Standards threatened to compromise the energy goals of the project. The requirement that exterior alterations be compatible with the historic nature of the property and not..."destroy historic...features and spatial relationships that characterize the property" became a challenge in consideration of the PV canopy, which would be visible from the street. The NHPA reviewers requested that the project team reduce or remove the PV canopy from the Aspinall Courthouse.

Removal of the PV canopy would have been a serious impediment to the net-zero energy goals of the renovation design, since the building would have to produce energy to offset its energy use over the course of a year. Chiefly, the reviewers faulted the design because it was visible from the street. The project team was able to redesign the PV canopy to completely eliminate its visual impact along a) the south façade and directly across the street, and $b$ ) the east and west sides of the building from the sidewalk level adjacent to the building. This tactic of reducing visual impact has become a common approach for meeting requirements of historic preservation while integrating newer technologies. ${ }^{21}$

${ }^{21}$ Kandt A; Hotchkiss, E; Walker, A.; Buddenborg, J.; Lindberg, J (2011). Implementing Solar PV Projects on Historic Buildings and in Historic Districts. NREL/TP-7A40-51297, Golden, CO: National Renewable Energy Laboratory. 
The smaller PV canopy affected the energy aspects of the overall renovation design. The alteration reduced the PV system from $170 \mathrm{~kW}$ to $123 \mathrm{~kW}$ (a 35\% reduction). This had an impact on the overall energy generation system that required the design team to incorporate additional energy efficiency measures to reduce energy demand. The additional measures included several deep retrofit measures and two additional geothermal heat pumps. The geothermal exchange system was not in the original design, but was added to accommodate the smaller PV canopy that resulted from the AHCP Section 106 review process, helping the project team reach net-zero energy goals.

\subsubsection{Ground-Source Exchange System}

The geothermal exchange system utilizes the consistent temperature of the earth to provide heating, cooling and hot water. The 475-foot vertical wells allow the building to reject heat into the ground or absorb heat from the ground depending on the time of year and the demand for heating or cooling. Because the ground is relatively constant at $64^{\circ} \mathrm{F}$ throughout the year, the HVAC and water system only need to alter the temperature a few degrees to condition the indoor space and heat water. As mentioned previously, geothermal exchange systems are approximately $45 \%$ more efficient than typical HVAC systems.

\section{Energy Modeling}

As challenges arose and the design team selected new building technologies to meet net-zero energy goals, energy models were modified. The design team altered the original energy model to include the new design scenarios. For example, after the historical review process resulted in a compromise to reduce the solar PV system size, the the estimated expected total project energy savings needed to be made up using the ground-source exchange system.

Figures 14 and 15 show the comparison between the modeled energy end-use and actual post occupancy metered energy use. The pie chart in Figure 14 shows the modeled end-use electrical consumption for the Aspinall Courthouse. Figure 15 shows the actual energy end use breakdown in February 2014. The model uses the constructed project and estimated tenant loads, whereas the actual end-use shows the data from metered equipment and systems in the completed building, post-occupancy. An example is the heating and cooling being generalized in the model, but being broken out into heat pump, variable refrigerant flow, and dedicated outdoor air supply (DOAS) in the actual data. Unregulated loads are those that lie within the tenant spaces, such as plug loads.

Conducting energy modeling frequently and updating models that simulate the measures needed to achieve net-zero energy goals, along with regular team reviews of the models, is essential to make informed construction and goal-making decisions. By modeling the reduction in PV and adding the geothermal exchange system, the project team could see whether net-zero energy goals would be achieved. The results from energy modeling are also useful to compare to actual consumption after building occupants have begun to use the building in its renovated state. The comparison informs improvements in future modeling and provides an assessment that may indicate systems that may need to be commissioned or modified to improve energy savings. 


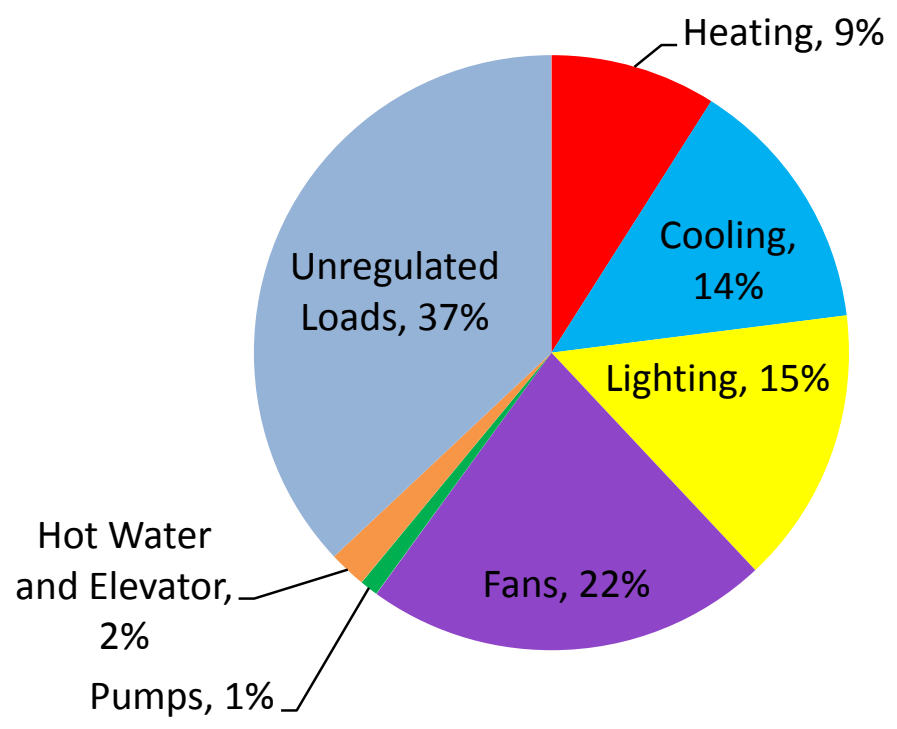

Figure 14. Modeled end-use electrical consumption in the Aspinall Courthouse

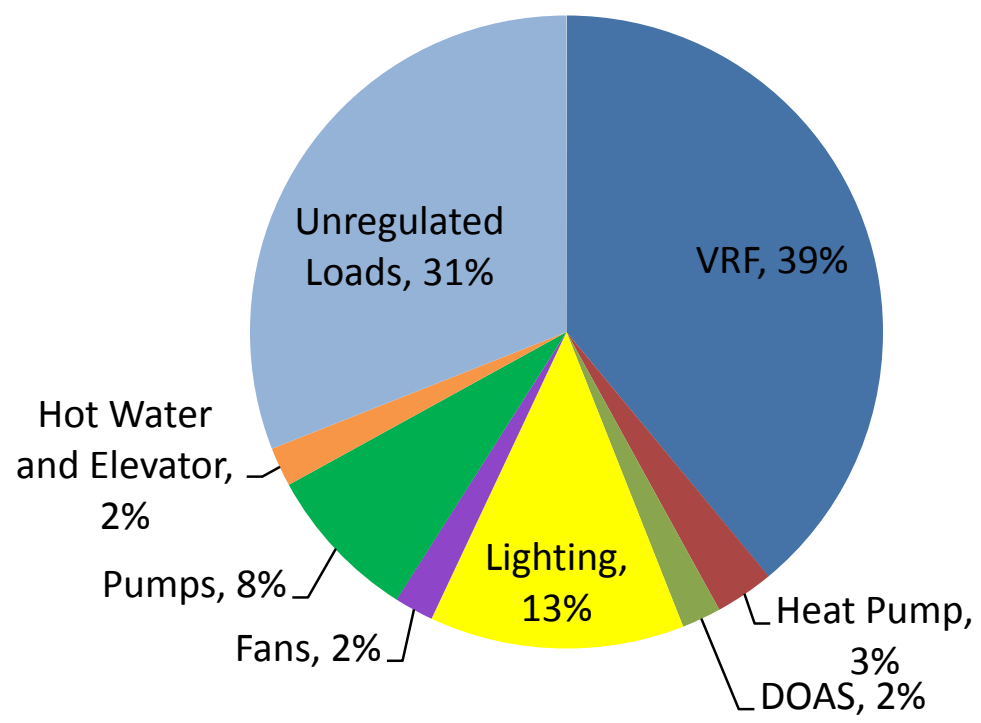

Figure 15. Actual end-use electrical consumption as of February 2014

\subsection{Commissioning Operations}

Commissioning is necessary in order for a building to achieve optimal performance. The Aspinall Courthouse follows a GSA Net-Zero Energy Management Plan, which includes requirements for reviewing the Building Management System for efficient operation. The plan includes steps related to commissioning and management of the building that apply to GSA staff or to contracted O\&M. 
Commissioning of the building following a renovation is crucial to determine whether systems are performing as designed and installed. During commissioning, each building system needs is tested and monitored to determine how it is performing and to troubleshoot any systems that are underperforming. Facility energy managers should take the measures identified in the commissioning report to optimize the building systems. A thorough commissioning process will incorporate monitoring of tenant use and behavior, as an element of determining whether facility managers are operating building systems to support building functions adequately. The net-zero management team will need to monitor all of these facets to ensure the building meets its energy performance potential, given its size, design and function.

The Aspinall Courthouse renovation project included a separate contract for one year following renovation completion to support data collection and analysis, identification of anomalies in energy consumption and solutions for addressing anomalies. The design-build and net-zero management team held weekly meetings to review and correct building system operation to review assumptions made in the energy model (based on construction documents from August 2011).

The project team focused on building performance and ensured the Aspinall Courthouse was within 5\% of its net-zero operations goal. The contractual goal was to ensure that the building systems installed under the contract operate at, or below, the estimated energy use gathered from the product literature and energy model. The tenant plug loads, however, were not included in this contract requirement since that was outside of the contractor's control, which is one reason they are modeled and metered as 'unregulated loads'. Contractual compliance through performance assurance focused on installed systems performing within a total of $5 \%$. One full year of enhanced $\mathrm{M} \& \mathrm{~V}$ is necessary to review systems in each season and make adjustments as necessary.

The team approached commissioning of the building systems in a three-step process. First, the energy model estimates were compared with actual energy use from monitored data. Next, if the total energy use was greater than the modeled use, the equipment was adjusted. Lastly, the monitored data collected after the adjustment was compared to the modeled data to determine if the adjustment had corrected the energy consumption of the system. The last two steps were repeated until the equipment functioned at the highest possible efficiency. ${ }^{22}$

Often, optimization of systems during commissioning requires simultaneous adjustments of other building systems to ensure that energy savings accomplished by one system do not correspondingly increase the energy use of another system. The building systems were broken into different categories (lighting, hot water, the elevator, variable refrigerant flow, dedicated outdoor air system, etc.), and the project team systematically optimized each of the systems individually, and then as a whole. This system commissioning approach was effective for the Aspinall Courthouse and could be replicated to achieve savings.

A specific example of the beneficial impact of $M \& V$ included in the Aspinall Courthouse postcommissioning operations lies within the geothermal system. The team found that the geothermal exchange system was using excessive amounts of energy. Further investigation led to the discovery that while the two pumps were designed to operate alternately, they were operating simultaneously. Once the pumps were reprogrammed, the energy consumption of the system aligned with the modeled energy data.

Another measure implemented during post-commissioning was the establishment of set-points for the building. The set-points were different than what many occupants in the building had become accustomed

\footnotetext{
${ }^{22}$ For more information on the various types of commissioning see DOE EERE's O\&M Guide, Section 7.2: www1.eere.energy.gov/femp/pdfs/OM_7.pdf.
} 
to, and ranged from $72^{\circ} \mathrm{F}$ to $75^{\circ} \mathrm{F}$ year-round. These set-points fall within the ASHRAE 55 Comfort Conditions standards for office buildings, ${ }^{23}$ as well as the Public Building Services $\mathrm{P}_{100}{ }^{24}$; however, it was important for the project team to reduce energy even further by adjusting the set-points. The team worked to educate tenants and adjust temperatures to a higher range in the summer $\left(75-78^{\circ} \mathrm{F}\right)$ and a cooler range in the winter $\left(69-72^{\circ} \mathrm{F}\right)$, allowing for more significant energy savings in the building.

The category of unregulated loads includes plug loads, as shown previously in Figure 15, which are estimated to be $35,000 \mathrm{kWh}$ higher than the annual target for unregulated loads. As a result of the building's overall envelope improvements and system upgrades, plug loads become the largest consumer category. GSA is working with tenant agencies to address plug loads as a separate, ongoing goal of reaching net-zero operations. GSA distributed a Tenant Guide as part of the occupant engagement strategy, which describes the installed systems, energy goals of each agency and ways in which occupants can address plug loads. Tenant agencies meet monthly to review plug load data, as well as Federal requirements for energy efficient office equipment procurement as a way to reduce plug load energy consumption.

All of the post commissioning operations are analyzed and compared. The energy use intensity comparison is a helpful exercise to undertake (shown in Figure 16) during post commissioning to review the targets and the actual performance of the building. The original target and calibrated target are from modeled data, whereas the 12-month gross is the actual energy consumption in the building. The 12month net data show the energy performance after commissioning; the PV system further reduces the onsite consumption. Renewable energy credits further move the goal to zero energy consumed. The plug load contribution was isolated to determine how much of an impact tenant control over their leased spaces has on the energy consumption of the building. The Aspinall Courthouse team included comparisons of median and Energy Star 100 buildings to benchmark the renovation improvements in energy consumption.

${ }^{23}$ ASHRAE Standard 55-2013 Thermal Environmental Conditions for Human Occupancy available at https://www.ashrae.org/news/2013/ashrae-publishes-2013-version-of-thermal-comfort-standard

${ }^{24}$ Public Building Services P100 is a GSA facilities standard establishing design standards and criteria for new buildings and renovations. More information is on the GSA website at www.gsa.gov/p100. 


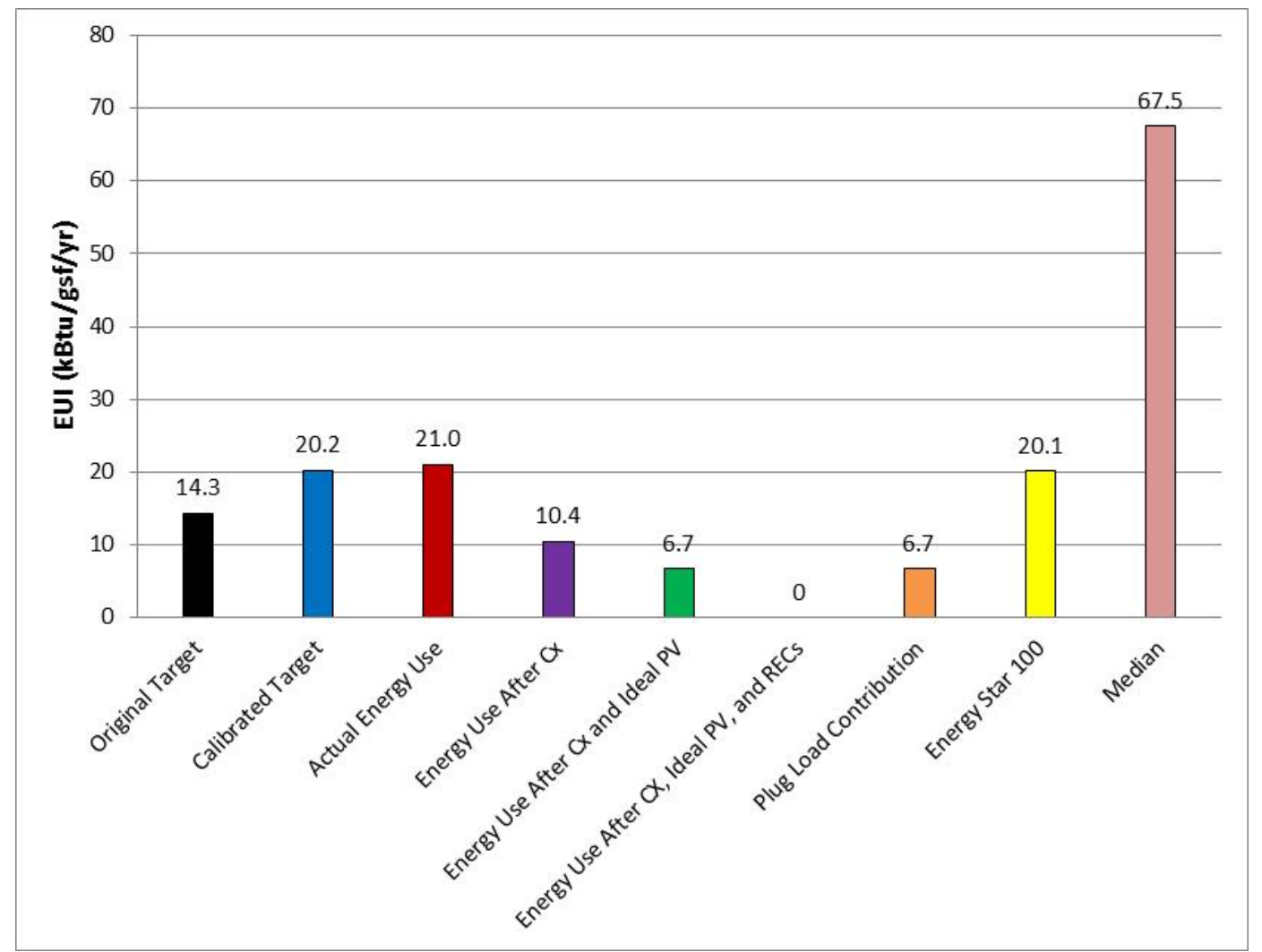

Figure 16. Energy use intensity comparison (March 2013-February 2014)

While some benefits of the renovation project can be measured, others are only qualitative. Quantitative benefits include reduced utility costs, reduced operations and maintenance expenditures, less frequent equipment replacement due to longer life-times, fewer work orders generated by occupant comfort complaints, lower absentee rate and staff turnover due to more comfortable working conditions, improved safety record, less overtime for maintenance staff, reduced backlog of preventive and reactive maintenance items. The qualitative benefits, some of which could be measured, but are not being measured by GSA, include reduced environmental impact of operations, public relations value for improved sustainability, greater thermal comfort, improved indoor air quality, reduced noise, better lighting quality, increased productivity and the flexibility to accommodate future changes to the building. 


\section{Lessons Learned}

The Aspinall Courthouse historic preservation and net-zero renovation is a prime example of potentially sweeping energy improvements in an existing Federal historic building. The project represents an unwavering commitment to historic preservation and sustainability. The renovation project set goals for energy efficiency and historic preservation while improving the indoor environmental quality to improve health and productivity for the building's occupants. The design-build approach acknowledged the federal government's goal to be carbon-neutral by 2030 and to create, through this project's design, a "green proving ground" demonstrating how to potentially make an existing historic building perform at net-zero energy, 17 years ahead of schedule. ${ }^{25}$

While the net-zero energy goals will not be realized until a full year's worth of energy consumption and production data have been obtained, the building has won many accolades and praise for successfully implementing energy efficiency measures, implementing far-reaching historic renovation measures and renewable energy features. During publication, the building had achieved ZEB-D status, but was continuing to work towards achieving ZEB-A

The challenges faced in designing and implementing the renovation to meet the aggressive goals set by GSA pushed all involved to think harder, think smarter, and test the bounds of what was thought to be possible. status. GSA is using the project to exemplify the "art of the possible" in existing buildings to achieve netzero energy goals. While this is the first of its kind, the hope is that other Federal and private sector facility managers will use the lessons learned from Aspinall and not shrink from the challenge to design and complete similar projects to determine the parameters for successful historic renovations that include net-zero energy measures.

The key lessons learned in the Aspinall renovation project include:

- Set targets early in the design process and revisit the targets throughout the renovation project to determine whether they are being met. Modifying measures and prioritizing targets will help keep the team on track to meet the goals established at the outset.

- Consider tenants and their energy needs early in the process. Some tenants, by virtue of their missions, may not agree to commit to zero energy building goals, which could make ZEB-A goals unattainable due to limited space for onsite renewables, or increasing costs for ZEB-B, C, and D.

- Assemble a team of dedicated members with the qualifications that will assist in attaining the established targets. A passionate, competent team is critical to a successful net-zero energy and historic preservation project. Regular meetings with open communication are essential to achieving goals.

- Conduct energy modeling frequently. Frequently updated models that simulate the measures needed to achieve net-zero energy goals, and regular team review of the models is essential to make informed construction and goal-making decisions.

- Include energy monitoring and sub-metering to the circuit level. This level of monitoring allows teams to isolate building system performance for each piece of equipment installed to ensure lowest possible energy draw and optimal performance. From a contract standpoint, it allows the

${ }^{25}$ www.gsa.gov/portal/content/180259 
owner to complete a more comprehensive commissioning process that includes energy performance as a part of system performance. Monitoring also allows the team/owner/property manager to isolate plug load consumption within the building and identify opportunities for individual energy use reductions, while also holding manufacturers accountable to meet energy performance claims in product literature.

- Include performance assurance or enhanced measurement \& verification language in contracts for a minimum of one year, post construction. This enables the owner to request the design-build team prove they have met contractual energy related targets, which are important to define within the contract. M\&V should include engineers, designers, contractor, sub-contractors, and manufacturer representatives. In addition, it may include other contracts such as the construction manager and commissioning agent. The purpose of the enhanced M\&V is to evaluate the new system's postconstruction actual performance as compared to expected energy performance at the design phase. Enhanced M\&V provides an opportunity to engage stakeholders to address system operation issues in each seasonal condition and make adjustments to align the system's operation and enhance system performance. In this way, enhanced $M \& V$ supports the energy design intent and extends stakeholders an opportunity to examine ways to enhance performance beyond the design intent if possible. This requires, at a minimum, bi-weekly meetings to assess energy data from energy monitoring at the circuit level then compare it to anticipated performance. Re-work by subcontractors and manufacturers will most likely be required during this period to meet or exceed energy design intents. This scope is much more involved than the traditional commissioning process, which primarily focuses on operational performance and adherence to the specifications.

- Include one year post-occupancy contracts with the Engineer of Record to assist property management and O\&M contractors to ensure proper management of the building systems. Contracts may be included in the scope of enhanced measurement \& verification and can assist in ongoing individual plug load management and occupant behavior. Typical contract language requiring 40 hours of training may not be sufficient for on-site O\&M property management staff to fully understand how new systems are intended to work. Nor does typical contract language address every site specific issue which may arise post occupancy. Contracts should allow these types of issues and concerns to be addressed by the design professional. The scope may assist in identifying performance warranty related issues, which may otherwise not be addressed and should bridge learning gaps to ensure systems are managed per the design intent. Contract language should allow the building manager and O\&M contractors or staff to meet with the engineer on an established basis through the one-year period to ask questions about systems and maximizing performance. The intent of this type of contract is to allow property managers and O\&M contractors to properly manage new equipment to ensure the longevity and enhanced performance of the new systems. Since building automation system (BAS) program logic may need to be changed based on outcomes of discussions among property management staff and the engineer, it may be beneficial to allocate funds for the BAS programming contractor.

GSA's experience shows that historic renovations incorporating net-zero energy goals can be considered in three discrete, sequential parts: historic renovation measures that align with deep energy retrofit or high performing new construction, post-occupancy modifications, and finally purchase of renewable energy.

The deep energy retrofit or high performing new construction is the largest investment. Energy performance should be monitored and addressed for a period of 1-2 years post-construction with occupants present in the building. During the 1-2 years post-construction, the project team should attempt to address tenant plug loads, engaging stakeholder tenants to reduce associated energy use to its bare minimum. Although monitoring in post construction will reveal much about tenant plug loads, tenant behavior modifications and information technology equipment discussions can begin long before the 
project is initiated and continue long after the project ends. Once the post construction $\mathrm{M} \& \mathrm{~V}$ is complete, plug loads can be better estimated based on the one year post occupancy.

The final phase should be the installation of renewable energy resources to compensate for the post occupancy energy demand. It is important to design buildings to be "renewable energy ready" so that solar PV or other technologies can be installed when they are financially viable. Early installation of renewable energy resources based on expected energy use runs the risk of miscalculating the necessary investment in renewable energy. Monitoring the building for one to two years post occupancy will provide an accurate energy profile and allow more informed decisions to be made regarding the amount of renewable energy needed to meet the building's energy goals.

The Aspinall Courthouse net-zero energy renovation has been a learning experience for the GSA, and the lessons-learned are valuable to the Federal government as each agency strives to meet net-zero energy goals. The successful completion of the Aspinall Courthouse historic preservation and net-zero renovation has set the bar high, and illuminates continuing steps on the path toward meeting national energy and sustainability challenges, with the Federal government leading the way.

The Aspinall renovation is one of the first historic renovation projects that incorporates net-zero energy aspects. As a result, the total costs of the project are challenging to benchmark with other similar projects. The Aspinall renovation was approximately $\$ 264 / \mathrm{ft}^{2}$, which included the costs of the solar PV installation. The National Renewable Energy Laboratory constructed the Research Support Facility (which is a net-zero new construction) for approximately $\$ 240 / \mathrm{ft}^{2}$ without the solar PV installation. The national average cost for office buildings that incorporate energy efficiency measures, such as LEEDcertified building projects, is $\$ 333 / \mathrm{ft}^{2}$. GSA believes the design-build contract and whole-building design approach kept the costs lower than they would be without these approaches. Costs were also lower due to the original design of the Aspinall building, which already incorporated features such as natural daylight and thermal comfort with passive design. Preservation and net-zero costs may have been much higher without these original design features. As more historic renovation projects incorporate net-zero energy aspects, the total costs of the projects would be interesting to compare. 
For more information, visit:

femp.energy.gov
FEMP:in

Federal Energy Management Program 